This is the author's version of a work that was published in the following source:

Schücking, M.; Jochem, P.; Fichtner, W.;

Wollersheim, O.; Stella, K. (2017)

Charging strategies for economic operations of electric vehicles in commercial applications w.

Transportation research / D, 51, 173-189. doi:10.1016/j.trd.2016.11.032

Please note: Copyright is owned by the author(s) and / or the publisher. The commercial use of this copy is not allowed 
Postprint of article "Charging strategies for economic operations of electric vehicles in commercial applications." In Transportation research / D, 51, 173-189. doi:10.1016/j.trd.2016.11.032 [-

\title{
Charging strategies for economic operations of electric vehicles in commercial applications
}

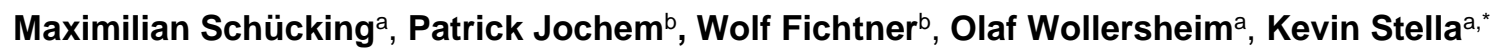

a Project Competence E, Karlsruhe Institute of Technology, Hermann-von-Helmholtz-Platz 1, D-76344

Eggenstein-Leopoldshafen, Germany

${ }^{b}$ Institute for Industrial Production (IIP), Karlsruhe Institute of Technology, Hertzstraße 16, D-76187

Karlsruhe, Germany

*Corresponding author: Tel. +49 721608 28243, E-mail address: kevin.stella@de.bosch.com

E-mail addresses: maximilian.schuecking@partner.kit.edu (M. Schücking), patrick.jochem@kit.edu (P. Jochem), wolf.fichtner@kit.edu (W. Fichtner), olaf.wollersheim@solarwatt.net (O. Wollersheim), kevin.stella@de.bosch.com (K. Stella)

\begin{abstract}
:
When substituting conventional with electric vehicles (EV) a high annual mileage is desirable from an environmental as well as an economic perspective. However, there are still significant technological limitations that need to be taken into consideration. This study presents and discusses five different charging strategies for two mobility applications executed during an early stage long-term field test from 2013 to 2015 in Germany, which main objective was to increase the utilization within the existing technological restrictions. During the field test seven EV drove more than $450,000 \mathrm{~km}$. For four out of five presented charging strategies the inclusion of DC fast charging is indispensable. Based on the empirical evidence five key performance indicators (KPI) are developed. These indicators give recommendations to economically deploy EV in commercial fleets. The results demonstrate that the more predictable the underlying mobility demand and the more technical information is available the better the charging strategies can be defined. Furthermore, the results indicate that a prudent mix of conventional and DC fast charging allows a high annual mileage while at the same time limiting avoidable harmful effects on the battery.
\end{abstract}

\section{Key-Words:}

Battery electric vehicles

Charging strategies

DC fast charging

Key performance indicators

\section{Introduction}

The electrification seems to be a very promising way to cut future $\mathrm{CO} 2$ emissions from road transport (Creutzig et al., 2015). This is especially true if the underlying electricity demand of electric vehicles (EV) is generated by carbon-free energy resources (such as wind or solar energy) (Ensslen et al., 2017; Jochem et al., 2015; Sohnen et al., 2015). Furthermore, EV show potential to reduce the oil dependency of western societies and decrease local emissions in urban areas, i.e. noise and local air pollutants such as SOx, particle matters, CO and NOx (Jochem et al., 2016). Concerning both aspects, a high life-time mile-age is desirable to fully utilize the EV emission saving potential (Stella et al., 2015).

However, EV are still a new technology and therefore face some hurdles that are currently limiting their market success considerably (Ensslen et al., 2014). Two of those hurdles are the limited range of current vehicles (about $150 \mathrm{~km}$ ) and their purchase prices that are considerably higher than the ones of their internal combustion engine driven counterparts (ICEV) (Dumortier et al., 2015). In commercial transport both limitations are easier to overcome than for private passenger car applications (Ketelaer 
Postprint of article "Charging strategies for economic operations of electric vehicles in commercial applications." In Transportation research / D, 51, 173-189. doi:10.1016/j.trd.2016.11.032 [?

et al., 2014). This is mainly due to the fact that for many applications trips are more predictable, single trips above the maximum range are more easily replaced by conventional cars, and the high purchase price of $E V$ can be negated by the higher annual mileage of commercial cars due to the lower variable costs of EV operation compared to ICEV (Bickert et al., 2015; Gnann et al., 2012; Plötz et al., 2015; Sierzchula, 2014).

Therefore, for environmental as well as economic motives the aim of this study is to increase the number of trips and hence the annual mileage of EV in commercial fleets. One essential part is the development of specific charging strategies that allow a high operating grade. These include the usage of fast charging infrastructure in order to show an economic advantageous application of current EV compared to conventional vehicles in an empirical field test (a detailed description of the research aim can be found in Section 2.4). The field test with several cross-border commuters from Alsace (France) to Karlsruhe (Germany) lasted from early 2013 till the end of 2015 . The research project behind was comprised of two different user groups: the first were fixed car-pooling commuter groups that travelled on average $75 \mathrm{~km}$ one-way from their homes in France to work in Germany; the second were employees on business trips during the day between two plant sites around $70 \mathrm{~km}$ apart, one in Germany and one in France. The EV were equipped with data loggers tracking battery as well as GPS data to allow a detailed technological and economic analysis.

The article is structured as follows: the second section provides an overview of the existing literature focusing on charging strategies, economic reasons as well as limitations of fast charging. It illustrates the gap in the literature and states the underlying research aim. The third section introduces the research project RheinMobil and the method by explaining the research design, setting and data collection. The fourth section is divided into five subsections; each describes and analyzes a different charging strategy that was implemented for the two mobility applications. The fifth section discusses the presented strategies in reference to the literature and introduces key performance indicators (KPI) for comparison. It also includes a small Total Cost of Ownership (TCO) analysis as well as a discussion of the technological implications. The last section concludes by summarizing the results, outlining the limitations and suggesting topics for future research.

\section{Literature review}

There are two main perspectives in the literature on the impacts of charging EV. One comprehensive focus deals with the impact on the electricity system (1) and the second focus considers the impact on the vehicle and the battery (2). There are several dimensions for focus (1). Some studies take a macroscopic point of view by looking at the impact on the electricity load and the resulting implications on the power plant portfolio and electricity grid (Babrowski et al., 2014; Camus et al., 2011;

Dharmakeerthi et al., 2014; Hadley and Tsvetkova, 2009; Hahn et al., 2013; Harris and Webber, 2014; Jansen et al., 2010), another emphasis is on additional emissions caused by electricity generation based on the timely distribution of charging (Bickert et al., 2015; Donateo et al., 2015; Ensslen et al., 2017; Jochem et al., 2015; Khoo et al., 2014; Muneer et al., 2015; Rangaraju et al., 2015; Sohnen et al., 2015; Thompson et al., 2011), still others aim on maximizing the input from (local) renewable energies (Atia and Yamada, 2015; Kier and Weber, 2015; Pantoš, 2011; Škugor and Deur, 2015; Wu et al., 2016). These topics are sometimes connected to different charging technologies such as controlled charging or even vehicle-to-grid (V2G) systems, providing virtual energy storage for grid services in the local electricity system (Bishop et al., 2016; Kristoffersen et al., 2011; Tomic' and Kempton, 2007). The second focus (2) is on vehicles and their batteries. Previous studies investigate the development of an optimized charging strategy from an EV perspective considering factors such as the state of health $(\mathrm{SOH})$ of the battery, cost optimized charging, including V2G, and parking time (Bashash et al., 2011; Neubauer et al., 2012). Other studies go even more into battery-related technical details by evaluating the charging and discharging behavior of the battery packs or even of individual cells (Kim et al., 2014; Onda et al., 2006; Rahimian et al., 2011). 
Postprint of article "Charging strategies for economic operations of electric vehicles in commercial applications." In Transportation research / D, 51, 173-189. doi:10.1016/j.trd.2016.11.032 [?

\subsection{Charging strategies for EV}

The understanding of the term charging strategy presented in this study differs from the one commonly used in the literature. In previous studies "charging strategy" is mostly applied in terms of timing the charging event (from an electricity grid perspective). Three options are mainly discussed: instant charging (uncontrolled charging), controlled charging (load and time), and V2G. The idea of controlled charging mainly focuses on avoiding load peaks and improving the electricity market efficiency by offering load shift potentials (flexibilization of electricity demand/demand response) (Axsen et al., 2011; Babrowski et al., 2014; Kang and Recker, 2009). Some studies analyze the real charging behavior of EV users in the context of timing, distribution, and type of charging (Khoo et al., 2014; Sun et al., 2015a, 2015b). Other "charging strategies" focus on sustaining a high SOH of the battery (Lunz et al., 2012). Our perspective starts from a mobility application that is focused on increasing the annual mileage of EV in order to replace mileage of ICEV. Therefore, not only the time and power of charging, but also the location is highly relevant.

Currently, many authors assume that charging takes place at home, at work or at other public electric vehicle supply equipment (EVSE) (Axsen et al., 2011; Neubauer et al., 2012; Speidel and Bräunl, 2014). The configuration of the EVSE varies between locations and countries depending on charging power, grid connections, and other technological standards (Azadfar et al., 2015). Previous research suggests that for first-time EV users, home charging is most convenient and most probable especially for households in rural areas, in suburbs or for people with access to city parking garages. However, charging at work or in public is also seen as realistic. Consequently recharging at work or public places leads to less demand for charging at home (Kang and Recker, 2009; Neubauer et al., 2012).

Developing a suitable charging strategy is highly dependent on the ratio of driving to parking time and the constraints set by customers, EV and the grid (Hahn et al., 2013). Lunz et al. (2012) suggest the following order of priorities: first, the vehicle owner's interest, second, grid stability, and as third priority grid support. The vehicle owner's interest is a combination of ensuring that the EV meets the personal mobility needs combined with economic aspects such as sustaining the battery $\mathrm{SOH}$ as well as personal attitude and further interests (Graham-Rowe et al., 2012). Concerning the ratio of driving to parking time many studies of conventional driving patterns or EV user behavior indicate that particularly privately used EV are not in use most of the time and are therefore available for charging; in average more than $22 \mathrm{~h}$ per day (Guille and Gross, 2009), or $80-96 \%$ of their lifetime (Camus et al., 2011; Lunz et al., 2012; Speidel and Bräunl, 2014). The EV spend more time than technologically required for the charging process at the EVSE (Speidel and Bräunl, 2014), and the charging time therefore has in average little impact on the EV feasibility (Greaves et al., 2014).

\subsection{Economic advantages and reasons for fast charging}

The high production costs of EV at the time of the field test in 2013, which were essentially the consequence of high battery prices (Plötz et al., 2013), have motivated research effort to identify and quantify potential savings in EV operations. In the context of charging some propose that potential economical savings lie in the use of V2G load shifting potentials during parking time. Simulations based on real driving patterns, different dynamic tariffs, and electricity market prices show that the potential cost reductions through controlled charging and V2G might reduce the TCO of EV in the future (Bunce et al., 2014; Dallinger et al., 2011; Ensslen et al., 2014). Even though commercial applications of EV seem to be more convenient there are only a few studies in this field, especially with empirical EV data (Kier and Weber, 2015; Škugor and Deur, 2015; Tomic' and Kempton, 2007). In terms of driving patterns, Robinson et al. (2013) show in their investigation of over 30,000 EV trips that commercially used pool vehicles have the highest amount of daily trips, but also the shortest trips on average. This underlines the technical and economic potential for EV in commercial fleets. 
Postprint of article "Charging strategies for economic operations of electric vehicles in commercial applications." In Transportation research / D, 51, 173-189. doi:10.1016/j.trd.2016.11.032 [?

Besides using potential savings through controlled charging, maximizing the availability and durability of the EV, to achieve a high annual as well as lifetime mileage might increase the competitiveness of commercial EV for some applications. The lower variable costs (fuel costs per $\mathrm{km}$ ) (Alexander and Davis, 2013; Linssen et al., 2012; Plötz et al., 2013) are mainly based on the higher efficiency of EV and the spread of fuel and electricity prices, which differ considerably between countries (cf. Table 1). In some countries, e.g. Norway, the benefits amount to 15 Euro- $\mathrm{Ct} / \mathrm{km}$. Furthermore, the costs for maintenance are seen to be 50-60\% lower compared to ICEV (Alexander and Davis, 2013; Richter and Lindenberger, 2010). However, due to limited long time experience there is still a high uncertainty in the real maintenance costs of EV.

One way to increase the availability of $E V$ is the implementation of fast charging. Fast charging in the context of this paper is defined as $\mathrm{C}$-rates of $1 \mathrm{C}$ or higher. The $\mathrm{C}$-rate stands for the relation of the applied charging current to the battery cell's capacity: e.g., for battery cells with a capacity of $40 \mathrm{Ah}$ a charging current of $120 \mathrm{~A}$ means a C-rate of 3 . According to IEC 61851-1 there are three different charging modes that are able to deliver charging power that goes beyond the standard single-phased outlet, which in Germany has a maximum charging power of max. $3.7 \mathrm{~kW}$ (one phase $16 \mathrm{~A} / 230 \mathrm{~V}$ ). In Germany two of them are used for passenger cars. In mode 3 the EV is charged with alternating current (AC). For passenger cars this is usually limited to $22 \mathrm{~kW}$ (three phases $32 \mathrm{~A} / 400 \mathrm{~V}$ ) charging power. In mode 4 the $E V$ is charged with direct current (DC), allowing maximum charging currents of up to $400 \mathrm{~A}$. Besides some exceptions, the few in 2013 available EV that were equipped with DC charging technology allowed a maximum charging power of $50 \mathrm{~kW}$. For EV with battery capacities around $20 \mathrm{kWh}$ (at that time most common in the market), AC charging with $22 \mathrm{~kW}$ leads to a charging rate of around $1 \mathrm{C}$, and $2 \mathrm{C}$ for $50 \mathrm{~kW} \mathrm{DC}$ charging. As a result a complete recharge would take $1 \mathrm{~h}$ or 30 min respectively (Bashash et al., 2011). Disadvantages of fast charging are the significant increase of investment for the EVSE (Neubauer et al., 2012), as well as the stronger impact and stress placed on the battery cells, which could harm them in the long run.

\begin{tabular}{lccc}
\hline & $\begin{array}{l}\text { Variable cost } \\
\text { (EV, Industry) } \\
\text { [Euro-Ct/km] }\end{array}$ & $\begin{array}{l}\text { Variable cost } \\
\text { (EV, Household) } \\
\text { [Euro-Ct/km] }\end{array}$ & $\begin{array}{l}\text { Fuel costs } \\
\text { (ICEV, gasoline) } \\
\text { [Euro-Ct/km] }\end{array}$ \\
\hline Canada & 1.347 & 1.599 & 8.580 \\
China & 1.309 & 1.686 & 8.905 \\
France & 1.899 & 2.913 & 12.415 \\
Germany & 2.551 & 5.840 & 12.740 \\
India & 1.515 & 1.667 & 8.125 \\
Japan & 2.958 & 4.112 & 13.000 \\
Norway & 1.101 & 2.379 & 16.445 \\
US & 1.033 & 1.836 & 6.305 \\
\hline
\end{tabular}

Table 1: Fuel costs for EV and ICEV in selected countries for 2013 (based on data from (Dudenhöffer et al., 2014; IEA, 2014; OECD, 2015; Wagner, 2014))

\subsection{Challenges of fast charging for the Li-lon battery}

One of the major problems at higher C-rates is the increased likeliness of lithium plating occurring on the anode. Plated lithium can destroy the separator resulting in short circuits and possible thermal runaways. Several studies have been reported dealing with these effects (Chandrasekaran, 2014; Kim et al., 2011, 2014; Offer et al., 2012; Onda et al., 2006; Vetter et al., 2005). 
Postprint of article "Charging strategies for economic operations of electric vehicles in commercial applications." In Transportation research / D, 51, 173-189. doi:10.1016/j.trd.2016.11.032 [?

Fast charging also increases ageing effects depending on various battery conditions. Battery degradation can have many causes, some of the key factors are the depth of discharge (DOD) and temperature (Fernández et al., 2013). At high and low SOC, due to chemical effects and secondary reactions, high currents stress cells more than in the mid SOC range (Agubra and Fergus, 2013; Broussely et al., 2005; Ecker et al., 2012; Vetter et al., 2005). Furthermore, high SOC is far worse for battery health than cycling (Lunz et al., 2012; Vetter et al., 2005). Too high or too low temperatures can also harm the cells (critical values depend on the cell chemistry and set-up). Higher charging currents lead to measurably higher local heating, which can result in a departure from the temperature range for ideal performance. A detailed explanation of ageing is beyond the scope of this article, but the potentially harmful effects underline the limitations and consequences of using fast charging to increase EV availability.

Even though fast charging is potentially harming the $\mathrm{SOH}$ of the battery, the time-limiting requirement by vehicles users is a serious challenge for the deployment of EV. Therefore, the US government has gone as far as setting $6 \mathrm{C}$ as an objective for future charging standards (Chandrasekaran, 2014).

\subsection{Research aim}

From the ecological as well as the economic point of view, a high annual EV mileage, resulting in emission and potential cost savings, is desirable when substituting ICEV with EV. On the other hand, there are the above-mentioned technological limitations that need to be taken into consideration. Therefore, this study proposes conceptual suggestions and provides empirical evidence from a longterm field test in Germany of how charging strategies for EV that enable a high annual mile-age under the technological restrictions can be implemented, assessed, and optimized based on different KPI. The concepts developed and conclusions drawn are based on real charging and mobility data as well as experience gathered in the development and execution of five different charging strategies in two mobility applications.

\section{Research method and data}

In order to answer the proposed research questions this paper takes a holistic experimental research approach, analyzing the development and application of different charging strategies according to their operational implications in two commercial applications. The field test was part of the research project RheinMobil, which itself was part of a greater publicly subsidized initiative financed by three different German Federal Ministries (Transport, Economics, and Research). RheinMobil itself was financially supported by the Federal Ministry of Transport and Digital infrastructure, which took no influence on the study design, data collection, analysis and interpretation of data. Its main objective was to demonstrate how EV are able to technologically and economically substitute ICEV and to maximize environmental benefits in commercial day-to-day operations: commuting and business trips (Stella et al., 2015). For this reason, three companies and two research institutions launched the project together in 2013. In order to demonstrate an economical application of EV, the annual mile-age should be high enough to compensate for the higher investment in purchasing the car. Accordingly, one key part of RheinMobil was the development and adaption of charging strategies that enable these high annual mileages and allow to prove the reliability of EV components under stringent conditions.

\subsection{Research setting}

RheinMobil focused on two different mobility applications: the commuting of car-pooling shift workers and internal business trips of employees between two plant sites. The two applications were selected according to a distinctive set of conditions:

- Firstly, the deployment and routing of the vehicles is constant.

- Secondly, the distance of a one-way trip does not exceed the realistic maximum range of the EV. 
Postprint of article "Charging strategies for economic operations of electric vehicles in commercial applications." In Transportation research / D, 51, 173-189. doi:10.1016/j.trd.2016.11.032 [?

- Thirdly, short recharging cycles allow for more than one or two trips per day on the selected routes.

Fulfilling these criteria ensures on the one hand that the EV offer an adequate range for the selected application, and on the other hand that, due to the high mobility demand on the route, a high operating grade and therefore mileage per year can be achieved. For both reasons it is essential that the routes travelled remain more or less constant and that the frequencies of use and charging time are almost completely predictable.

In the first mobility application, the commuting of shift workers in established car-pool groups provides a sensible application for an economically feasible e-mobility transport solution. Different studies have already identified the high potential of EV for commuting (Brunnert, 2012; Linssen et al., 2012; Richter and Lindenberger, 2010; Tomic' and Kempton, 2007). Our application fulfills the criteria of fixed travel times and routes: the groups leave and arrive at regular times based on the shift schedule and they keep to their usual commuting routes. Furthermore, all parking places are equipped with EVSE and the commuting distances are rather long, on average $75 \mathrm{~km}$ one-way (cf. Table 2). This leads to an annual mileage for a single shift worker of about $36,000 \mathrm{~km}$.

\begin{tabular}{lll}
\hline & $\begin{array}{l}\text { Application 1: Commuting of car- } \\
\text { pooling shift workers }\end{array}$ & $\begin{array}{l}\text { Application 2: Business trips } \\
\text { between sites }\end{array}$ \\
\hline User group & Employees in shift production & All employees \\
User per EV & $5-7$ people & $1-4$ people \\
Fixed user group & Yes, fixed group(s) per EV & No, changing each trip \\
Time of use & Around the clock, 7 days a week & $7 \mathrm{am}-8 \mathrm{pm}, 5$ days a week \\
One-way distance & $75 \mathrm{~km}$ & $70 \mathrm{~km}$ \\
Average speed & $55 \mathrm{~km} / \mathrm{h}$ & $71 \mathrm{~km} / \mathrm{h}$ \\
EV & $3 \mathrm{e}-$ Wolf Delta 2, 3 e-Wolf Delta 2 (EVO) & 1 Nissan Leaf \\
Charging locations & Home and at work & Both plant sites \\
Charging & 12 standard outlets (max. $3.7 \mathrm{~kW})$ & 1 standard outlet (max. $3.7 \mathrm{~kW})$ \\
infrastructure & 1 e-Wolf CHAdeMO (max. $30 \mathrm{~kW})$ & 2 Siemens CHAdeMO (max. $50 \mathrm{~kW})$ \\
\hline
\end{tabular}

Table 2: Overview of the two selected mobility applications

In the second mobility application, the business trips of employees between two production sites, not all of our set criteria are met. Trips are in this case less predictable, the user groups change and also the time of use varies. This creates uncertainty for charging times. Nevertheless, the route remains (more or less) constant and distances are similar, on average $70 \mathrm{~km}$. One single trip per workday leads to an annual mileage of about $34,000 \mathrm{~km}$.

All EV in the project were chosen according to technological and user specific requirements of the two applications. The first main condition was that batteries had to have sufficient capacity to ensure that even under restrictive conditions such as cold temperatures the EV would still be able to travel at least one way without the need of recharging. The second main condition was DC fast charging. In Germany at the starting time of the project, in 2013, the only available technology for DC fast charging (mode 4) was with the CHAdeMO system with a charging rate of up to $50 \mathrm{~kW}$. Besides the sufficient range and option to fast charge, the EV were also selected according to the installed cell technology. The battery cells needed enough cycle stability under the planned fast charging conditions to 
Postprint of article "Charging strategies for economic operations of electric vehicles in commercial applications." In Transportation research / D, 51, 173-189. doi:10.1016/j.trd.2016.11.032 [?

sufficiently allow the proposed intensive use of fast charging without quickly showing significant capacity losses. In addition to the technological requirements the EV needed to fit the demands of the travelers concerning size and comfort. Since the commuters travelled in groups of up to seven people and the employees on business trips were travelling in groups of one to four people the EV had to have at least that amount of seats (cf. Table 2). The only two EV that were fulfilling these conditions and were available in Germany in early 2013 were the e-Wolf Delta 2 and the updated EVO-version for the commuters and the Nissan Leaf for the business trips. In total seven EV were deployed in the field test. The detailed technological data for both EV can be found in Table 3.

\begin{tabular}{|c|c|c|c|}
\hline Technical Data & e-Wolf Delta 2 & e-Wolf Delta 2 EVO & Nissan Leaf \\
\hline Number of deployed EV & 3 & 3 & 1 \\
\hline $\begin{array}{l}\text { Traction battery capacity } \\
\text { (nominal) }\end{array}$ & $24.2 \mathrm{kWh}$ & $32 \mathrm{kWh}$ & $24 \mathrm{kWh}$ \\
\hline $\begin{array}{l}\text { Traction battery voltage } \\
\text { (max.) }\end{array}$ & $720 \mathrm{~V}$ & $720 \mathrm{~V}$ & $360 \mathrm{~V}$ \\
\hline Cell technology & Li-ion NMC & Li-ion NMC & Li-ion LMO-NCA \\
\hline $\begin{array}{l}\text { Energy consumption } \\
\text { (NEDC) }\end{array}$ & $187 \mathrm{Wh} / \mathrm{km}$ & $200 \mathrm{Wh} / \mathrm{km}$ & $173 \mathrm{Wh} / \mathrm{km}$ \\
\hline Maximum range (NEDC) & $154 \mathrm{~km}$ & $165 \mathrm{~km}$ & $175 \mathrm{~km}$ \\
\hline Peak performance & $90 \mathrm{~kW}$ & $90 \mathrm{~kW}$ & $80 \mathrm{~kW}$ \\
\hline Cabin heating & Bio-Diesel & Bio-Diesel & HV-Battery \\
\hline Vehicle mass (empty) & $1,666 \mathrm{~kg}$ & $1,650 \mathrm{~kg}$ & $1,525 \mathrm{~kg}$ \\
\hline $\begin{array}{l}\text { AC charging power } \\
\text { (nominal) }\end{array}$ & $2.6 \mathrm{~kW}$ & $2.5 \mathrm{~kW}$ & $2.3 \mathrm{~kW}$ \\
\hline AC plug type & $\begin{array}{l}\text { Type } 2 \\
\text { (EN } 62196 \text { - 2) }\end{array}$ & $\begin{array}{l}\text { Type } 2 \\
\text { (EN } 62196 \text { - 2) }\end{array}$ & $\begin{array}{l}\text { Type } 1 \\
\text { (SEA J1772) }\end{array}$ \\
\hline AC charging mode & Mode 1 & Mode 1 & Mode 2 \\
\hline DC charging power & Up to $30 \mathrm{~kW}$ & Up to $30 \mathrm{~kW}$ & Up to $50 \mathrm{~kW}$ \\
\hline DC communication protocol & CHAdeMO & CHAdeMO & CHAdeMO \\
\hline DC plug type & Harting & Harting & CHAdeMO \\
\hline Data logger & $\begin{array}{l}\text { On-board CAN } \\
\text { and GPS Logger }\end{array}$ & $\begin{array}{l}\text { On-board CAN and } \\
\text { GPS Logger }\end{array}$ & $\begin{array}{l}\text { Online overview, On- } \\
\text { board OBD and GPS }\end{array}$ \\
\hline
\end{tabular}

Table 3: Technological data of the applied EV

Besides the differences listed in Table 2, the applications can be distinguished from each other by their different requirements on charging technology. Similar to the EV, the conductive charging infrastructure was selected according to the technological requirements set by the two different mobility applications. In the case of commuting, EV can be deployed without the necessity of fast charging EVSE. Both time spans at home and at work are sufficient for conventional full charging cycles. However, during the field test it became necessary to install a fast charging station at the plant 
Postprint of article "Charging strategies for economic operations of electric vehicles in commercial applications." In Transportation research / D, 51, 173-189. doi:10.1016/j.trd.2016.11.032 [?

site in order to create the potential to increase the annual mileage significantly (c.f. Table 4). ${ }^{1}$ This goes hand in hand with a developed car sharing principle between all commuting groups, which is described in Section 4.1 below. For the business trips between the two plant sites the time span is heterogeneous and mostly not sufficient for conventional charging; in particular, usual meetings with durations of less than two hours do not mesh with the conventional charging technology. Accordingly, on both ends DC fast charging EVSE was installed right from the beginning (c.f. Table 4).

\begin{tabular}{lll}
\hline & e-Wolf EW-DC-30 & Siemens CP3000 \\
\hline Input voltage & 3-phased 340 - 460 V AC & 3-phased 400 V AC \\
Input current & $64 \mathrm{~A}$ & $80 \mathrm{~A}$ \\
Efficiency & $<95.5 \%$ & $<94 \%$ \\
Output voltage & $500-700 \mathrm{~V} \mathrm{DC}$ & $50-500 \mathrm{~V} \mathrm{DC}$ \\
Output current & Max. 50 A & Max. 120 A \\
Output power & Max. 30 kW & Max. 50 kW \\
Plug type & Harting & CHAdeMO \\
Communication protocol & CHAdeMO & CHAdeMO \\
DC charging mode & Mode 4 (IEC 61851-1) & Mode 4 (IEC 61851-1) \\
\hline
\end{tabular}

Table 4: Technical parameters of fast charging EVSE installed in the project

\subsection{Data collection}

During the field test the EV were equipped with data loggers. The e-Wolf Delta 2 data loggers (VIKMOTE VX 20, Vikingegaarden) were connected directly to the CAN-bus of the vehicle and constantly send their data via UMTS to the online server data base. With timely equidistant data points, the following vehicle and GPS data was recorded: date and time, voltage in the $12 \mathrm{~V}$-battery, voltage in the low voltage-circuit, several parameters of the high-voltage-battery, such as voltage, mean cell voltage, battery current, medium cell temperature, and SOC, as well as remaining range, speed and odometer based on axis turning, GPS height, GPS odometer, GPS speed, GPS position latitude and longitude, and address according to GPS. The data can be ascribed to the individual cars and user groups. The data logger was active while the ignition was switched on as well as during charging processes. For the data collection of the Nissan Leaf two different approaches were taken. Mainly a conventional online platform provided by the OEM to review the energy consumption and operation of the EV was used. This database shows the current SOC, the remaining range, and whether the vehicle is currently charged or not. Additionally, it lists historical data such as trips made, distances travelled, energy consumed by the engine, energy consumed by the auxiliaries, energy recuperated through regenerative breaking and travel time. To record the charging curves as well as to assess the accuracy of the online data for a five-month period an extra data logger directly connected via Blue-tooth to the EVs on-board diagnostic system (OBD) was installed. This allowed detailed access to a wide range of additional data, e.g. battery currents, voltages, temperatures, SOC, $\mathrm{SOH}$, charging status as well as GPS data. From early 2013 to the end of 2015 , over 450,000 km of

\footnotetext{
${ }^{1}$ Since the e-Wolf EV had a board voltage above $600 \mathrm{~V}$, for which both DC-fast standard charging plugs CHAdeMO and CCS are not certified, e-Wolf built a special charging station, which worked on the open source CHAdeMO protocol, but used the Harting plug, which comes from railway technology and is certified up to $1000 \mathrm{~V}$.
} 
Postprint of article "Charging strategies for economic operations of electric vehicles in commercial applications." In Transportation research / D, 51, 173-189. doi:10.1016/j.trd.2016.11.032_]

fully electrically driven mileage as well as over 5000 conventional and $650 \mathrm{DC}$ fast charging events were logged.

\section{Charging strategies for an economical application of electric commercial cars}

In the following we present and evaluate five different charging strategies, which allow a significant increase of the EV operating grade. The first three (1.1-1.3) refer to the commuting application: the first solely relying on conventional $A C$ charging, the other two including $D C$ fast charging for achieving a higher annual mileage. The remaining two charging strategies (2.1 and 2.2) belong to the business trip application.

\subsection{Charging strategies for commuting shift workers}

The three charging strategies applied for the commuting case can be directly connected to the premises set by the shift schedule as well as the travelling routes and times. In the current shift system, the car-sharing groups leave their home roughly two hours before the start of the shift, drive about $75 \mathrm{~km}$ to the plant and pick up colleagues on the way. They arrive about $30 \mathrm{~min}$ before the start of the shift at $6 \mathrm{am}, 2 \mathrm{pm}$, or $10 \mathrm{pm}$. Each shift lasts $8 \mathrm{~h}$ and after the shift they immediately start their journey back to their homes where they arrive about one and a half hours later. Each new charging strategy rep-resents an increase in the possible annual mileage.

\subsubsection{Strategy 1.1: Relying on conventional charging (mode 2) only for one user group per EV}

The first charging strategy was developed based on the technological data of the charging processes (mode 2), the energy consumption of the EV and the shift schedule of one commuter group. With $8.5 \mathrm{~h}$ at work and $12.5 \mathrm{~h}$ at home available for recharging (cf. Fig. 1) and an effective measured power after considering charging losses of around 2.30 or $2.19 \mathrm{~kW}$ respectively (c.f. Fig. 2 and Table 5), the theoretical maximum energy that can be recharged at work is about $18.7 \mathrm{kWh}$ and $27.5 \mathrm{kWh}$ at home. With a measured average energy consumption of about $230 \mathrm{Wh} / \mathrm{km}$ (NEDC is $187 / 200 \mathrm{Wh} / \mathrm{km}$, c.f. Table 3) the maximum distance that can be covered by a recharge at work is about $81 \mathrm{~km}$. The average distance of a one-way journey lies at around $75 \mathrm{~km}$ and the energy consumption therefore is $17.25 \mathrm{kWh}$, which requires about $8 \mathrm{~h}$ of recharge. Accordingly, for each EV deployed one conventional charging point is required on each end of the route. The calculations show that during the working shift almost the whole time is required for charging. At home only around $2 / 3$ of the available time is needed for charging. With this charging strategy an annual mileage around $36,000 \mathrm{~km}$ a year can reached. Based on the average distance of $75 \mathrm{~km}$ the total charging time is about $16 \mathrm{~h}(66.7 \%)$, the total driving time is $3 \mathrm{~h}(12.5 \%)$, and finally the idle time equals $5 \mathrm{~h}(20.8 \%)$. The complexity for the vehicles users of this strategy is very simple since it did not involve switching $\mathrm{EV}$ or using different charging technologies.

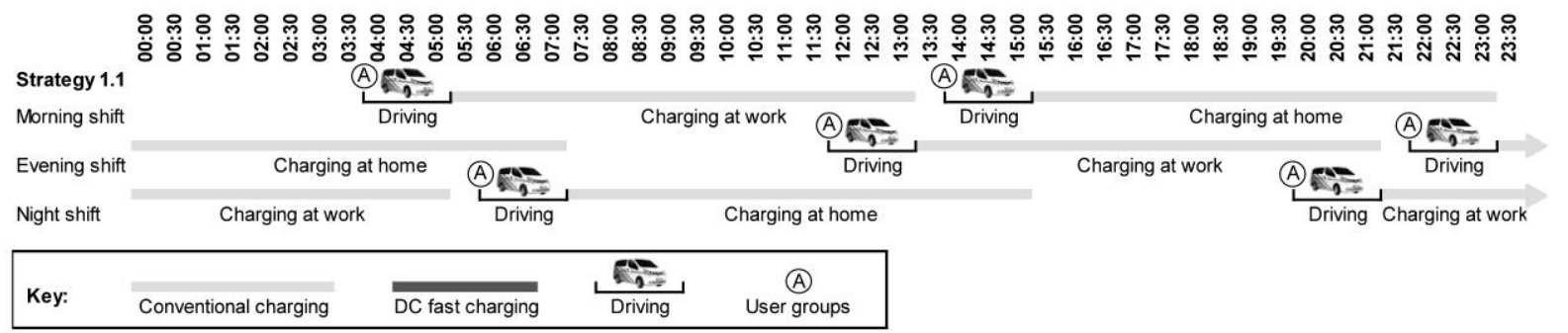

Figure 1: Illustration of the commuting charging strategy 1.1 
Postprint of article "Charging strategies for economic operations of electric vehicles in commercial applications." In Transportation research / D, 51, 173-189. doi:10.1016/j.trd.2016.11.032 [z

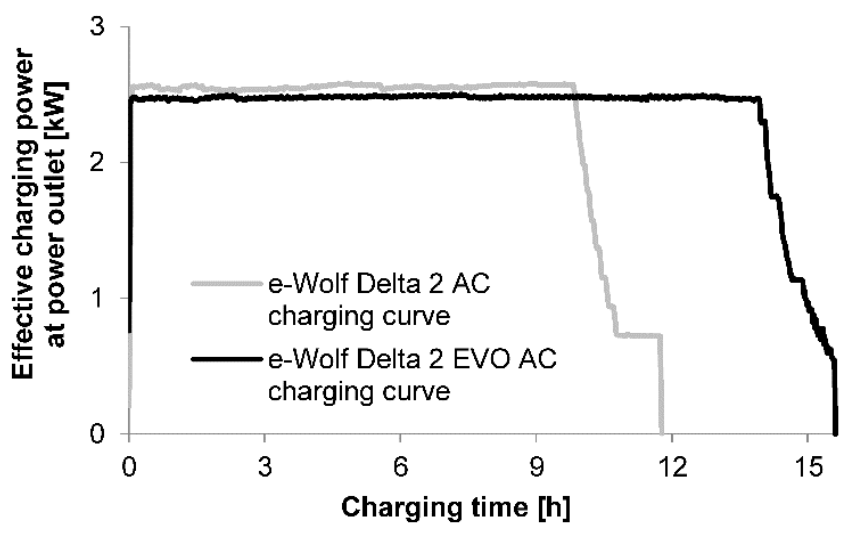

Figure 2: Conventional AC charging curves of the e-Wolf Delta 2 and Delta 2 EVO

\begin{tabular}{lrr}
\hline & e-Wolf Delta 2 & e-Wolf Delta 2 EVO \\
\hline SOC span & $0-100 \%$ & $0-100 \%$ \\
$\begin{array}{l}\text { Charging time for a full } \\
\text { recharge [h] }\end{array}$ & 11.78 & 15.60 \\
$\begin{array}{l}\text { Max. effective charging } \\
\text { power at outlet [kW] }\end{array}$ & 2.58 & 2.50 \\
$\begin{array}{l}\text { Max. effective battery } \\
\text { charging power [kW] }\end{array}$ & 2.30 & 2.19
\end{tabular}

Table 5: Data conventional AC charging curves of the e-Wolf Delta 2 and Delta 2 EVO

4.1.2 Strategy 1.2: Using fast charging to enable three or four user groups to share two EV In order to increase the annual mileage, it becomes necessary to assign more than one commuter group to each EV. Based on the shift schedule, three or four groups that work different shifts are required to share two EV amongst them. While the travel distances and the time for recharging at the plant remain constant, the time available for recharging at home changes: once a group arrives at home another group uses the EV to get to their next shift. The available charging time is reduced to $4.5 \mathrm{~h}$. Fig. 3 illustrates the strategy 1.2 by showing the driving and charging schedule over three days for one EV and three user groups.

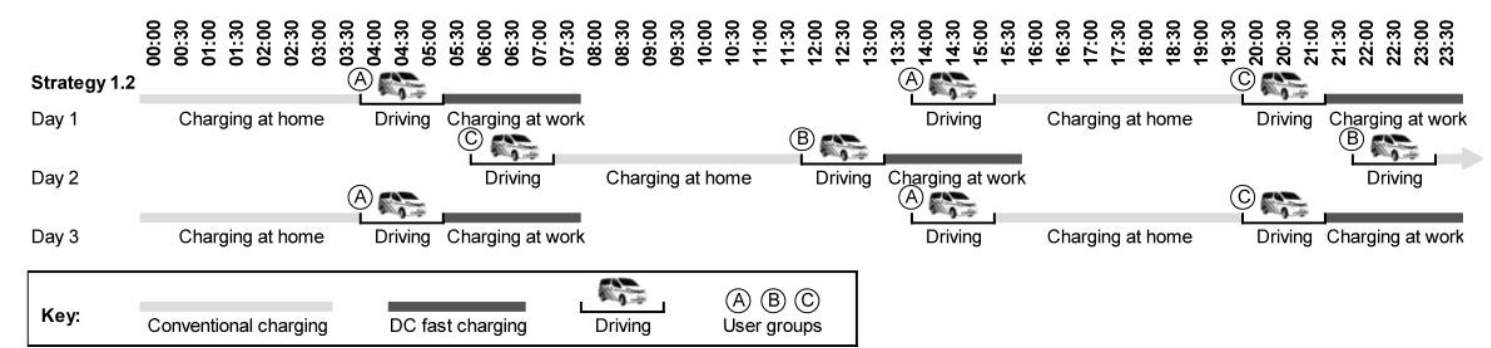

Figure 3: Illustration of the commuting charging strategy 1.2

The shorter available charging time at home requires the installation of DC fast charging at the plant site. Calculating with an effective conventional AC charging rate of $2.19 \mathrm{~kW}$ (cf. Fig. 2) and the energy consumption of about $17.25 \mathrm{kWh}$ per trip, it becomes obvious that the reduced charging time at home, in which only about $9.9 \mathrm{kWh}$ can be recharged, is insufficient. As can be seen in Fig. 4 both the Delta 2 and Delta 2 EVO cannot constantly operate under these requirements. While the Delta 2 can 
Postprint of article "Charging strategies for economic operations of electric vehicles in commercial applications." In Transportation research / D, 51, 173-189. doi:10.1016/j.trd.2016.11.032 [?

accomplish only one round-trip, the Delta 2 EVO comes to an end after three round-trips. Only the fast charging infrastructure at the plant site allows sustainable operation of this strategy.

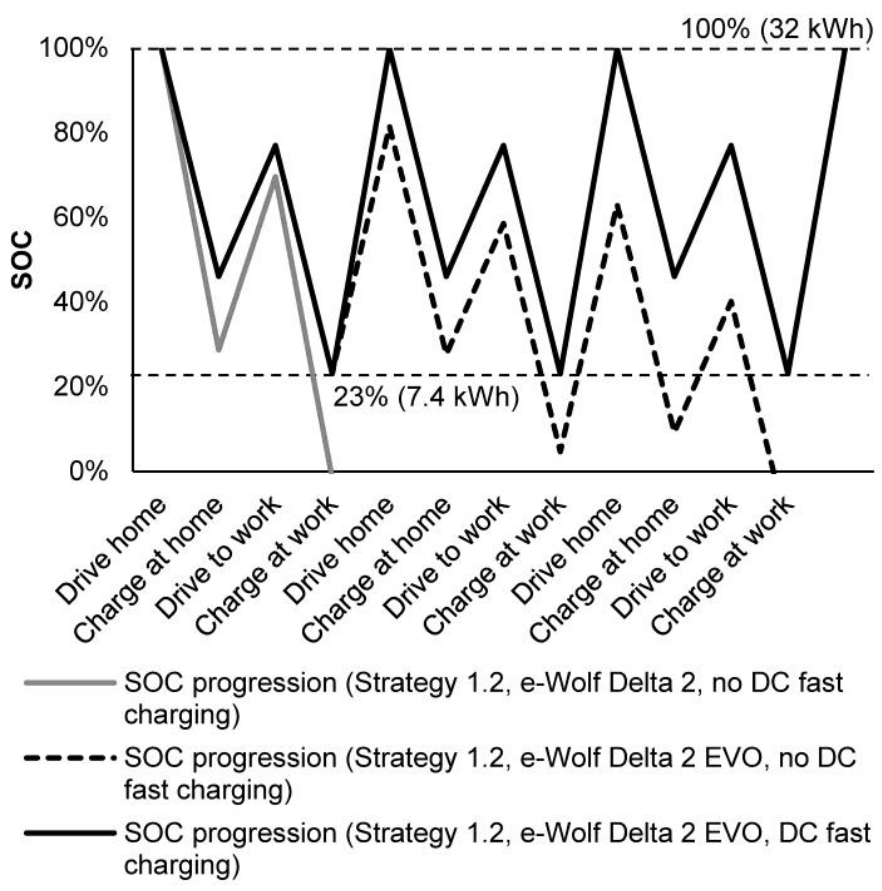

Figure 4: Development of SOC for strategy 1.2 with and without DC fast charging station

Based on the charging power and duration of the DC fast charging process as well as the energy consumption of the EV the charging strategy 1.2 was elaborated (cf. Fig. 3). The reduced charging time of $4.5 \mathrm{~h}$ is compensated by the use of fast charging at the plant. With the maximum effective charging power of about $26 \mathrm{~kW}$ and a maximum time of $2.5 \mathrm{~h}$ for a full recharge (c.f. Fig. 5 and Table 6 ) the parking time at the plant is more than sufficient. Therefore, the time lacking for recharging at home can be more than compensated through DC fast charging at work. In this strategy the Delta 2 EVO's battery capacity of $32 \mathrm{kWh}$ is sufficient to ensure that there is enough energy remaining for the way to the plant, including a satisfactory additional energy reserve. This operation schedule leads to an annual mileage of between $54,000 \mathrm{~km}$ (for three groups sharing two cars) and 72,000 km (for four groups sharing two cars) per EV. The total charging time is either $13.5 \mathrm{~h}(56.25 \%$, day 1$)$ or $7.5 \mathrm{~h}$ $(31.25 \%$, day 2$)$. The total driving time per day is constant with $4.5 \mathrm{~h}(18.75 \%)$. In the remaining 6 or $12 \mathrm{~h}$ the EV is neither being charged nor used, respectively. The number of conventional and fast charging events is different for the two days. During day one, two fast and only one conventional charging events are started; on day two, two conventional and one fast charging event take place, on average 1.5 per day. Even though on average the number of charging events is equal, distinctly more energy is effectively recharged through fast charging. In 1.5 charging events $36.9 \mathrm{kWh}$ are recharged by DC charging and only $14.84 \mathrm{kWh}$ through conventional charging. All the groups using the EV have to work in different shifts as can be seen comparing day 1 and day 2 in Fig. 3 . Hence for the two EV shared by the three or four com-muting groups only one fast charging outlet is required. 


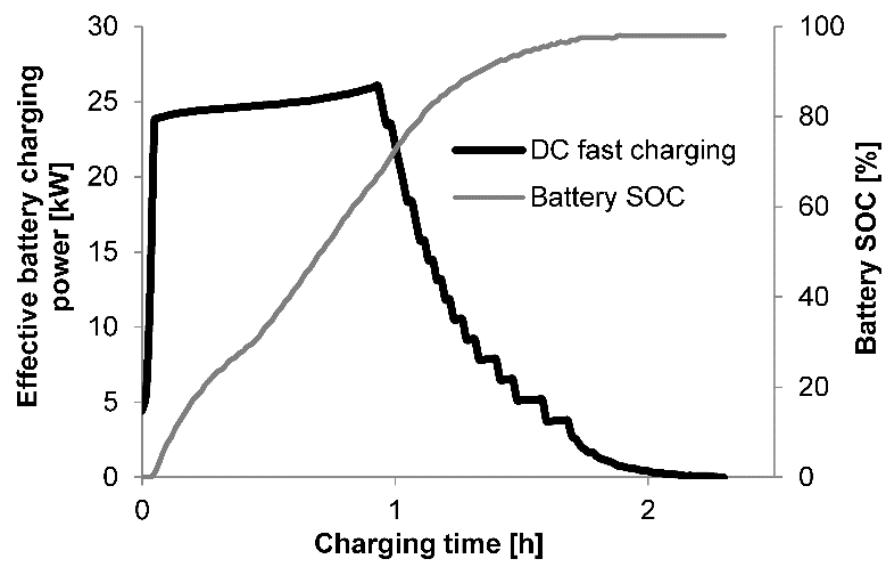

Figure 5: DC fast charging curve of the e-Wolf Delta 2 EVO

e-Wolf Delta 2 EVO

\begin{tabular}{lr}
\hline SOC span & $0-100 \%$ \\
$\begin{array}{l}\text { Charging time for a full } \\
\text { recharge }[\mathrm{h}]\end{array}$ & 2.30 \\
$\begin{array}{l}\text { Max. effective charging } \\
\text { power at outlet }[\mathrm{kW}]\end{array}$ & 30.00 \\
$\begin{array}{l}\text { Max. effective battery } \\
\text { charging power }[\mathrm{kW}]\end{array}$ & 26.04
\end{tabular}

Table 6: Data DC fast charging curve of the e-Wolf Delta 2 EVO

\subsubsection{Strategy 1.3: Using fast charging to enable three or four user groups to share one EV} Charging strategy 1.3 provides the opportunity to increase the annual mileage of the EV even further. The underlying model allows three of four different shift groups to continually share one EV as follows: (i) the first group drives to work, arrive about 30 min before the start, and immediately charge the EV; (ii) the second group leaves the plant 30 min later and travels back home, where the EV has $4.5 \mathrm{~h}$ for recharging until (iii) the third group takes it to drive to the plant and after a recharge of 30 min hands it over again to the first group, and so on. Fig. 6 illustrates an EV on two consecutive days deployed in this model.

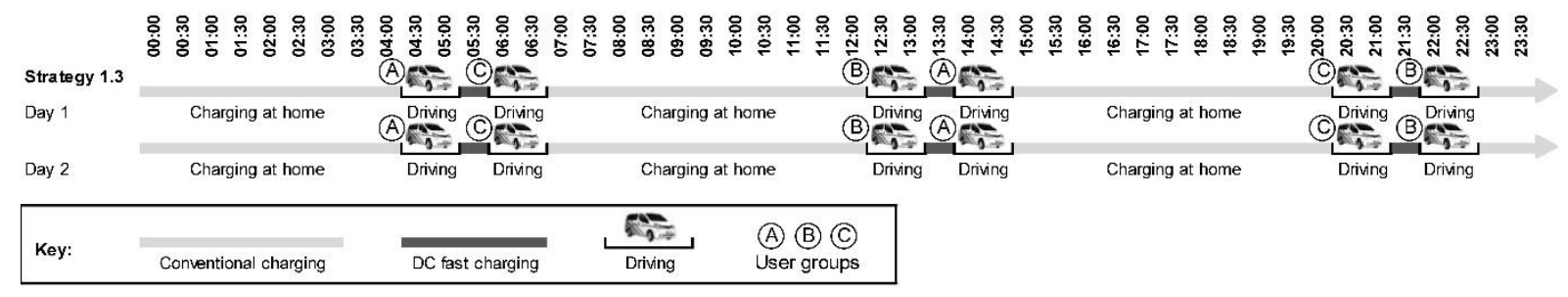

Figure 6: Illustration of the commuting charging strategy 1.3 (distance $50 \mathrm{~km}$ )

Under the field test conditions strategy 1.3 could not be implemented. The idea of this strategy was developed before the start of the project. With an average distance of $75 \mathrm{~km}$ per journey, an average energy consumption of $230 \mathrm{Wh} / \mathrm{km}$, and charging times of 0.5 or $4.5 \mathrm{~h}$ respectively the model proved unsustainable. As can be seen in Fig. 7, after the second recharge at home the energy stored in the battery is insufficient to drive the EV back to the plant. 
Postprint of article "Charging strategies for economic operations of electric vehicles in commercial applications." In Transportation research / D, 51, 173-189. doi:10.1016/j.trd.2016.11.032 [?

Reducing the average commuting distance can make the charging strategy and the underlying occupancy model sustain-able. Reducing the average distance has two positive effects. Firstly, the shorter distance reduces the energy consumption per trip. Only $11.5 \mathrm{kWh}$ are required for a $50 \mathrm{~km}$ journey. Secondly, a shorter distance also reduces the travelling time from $1.5 \mathrm{to} 1 \mathrm{~h}$ and therefore enhances the available time span for recharging at home from 4.5 to $5.5 \mathrm{~h}$ (cf. Fig. 6).

At an average distance of $50 \mathrm{~km}$ the charging strategy 1.3 becomes sustainable. The required energy per trip of $11.5 \mathrm{kWh}$ can be charged conventionally at home, where the maximum recharge in $5.5 \mathrm{~h}$ is $12.1 \mathrm{kWh}$, and at work, where the maxi-mum recharge in the $30 \mathrm{~min}$ is $13.5 \mathrm{kWh}$. Due to the fact that the DC fast charging power is significantly reduced at high SOC (cf. Fig. 5) the charging status of the EV never again reaches $100 \%$ SOC. After a few trips the process with its fixed time slots for charging stabilizes by utilizing the higher available DC charging power. Then the SOC range lies between $51 \%$ (16.34 kWh) and $89 \%$ (28.44 kWh) (cf. Fig. 7). This way of deployment leads to an annual mileage of around $100,000 \mathrm{~km}$. The total charging time per day is $18 \mathrm{~h} \mathrm{(75 \% )}$ and total driving time $6 \mathrm{~h}(25 \%)$ respectively. For this strategy the number of fast and conventional charging events started per day is 3 each. In these $36.3 \mathrm{kWh}$ is charged conventionally and $32.7 \mathrm{kWh}$ is recharged through DC fast charging. Since all the groups participating have to work in different shifts, again one DC fast charging EVSE is required.

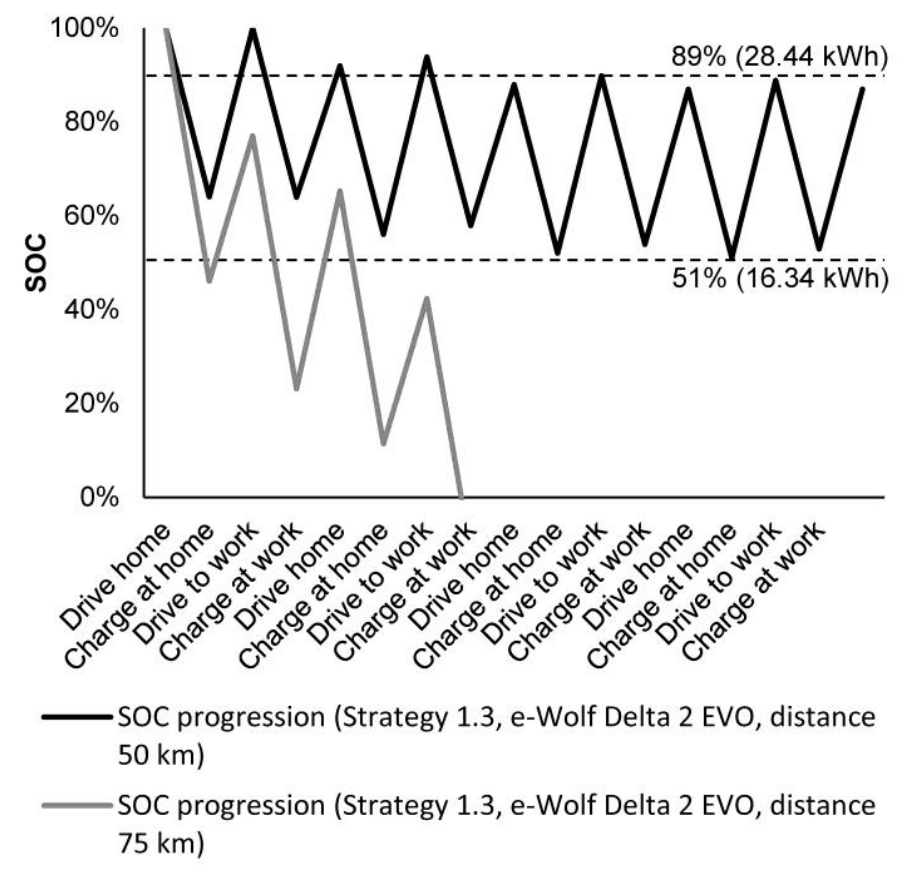

Figure 7: Development of SOC for strategy 1.3 for 75 and $50 \mathrm{~km}$ average distance

\subsection{Charging strategies for business trips between plants}

For the business trips application there was no fixed schedule available to fit the charging strategy to. The groups consist of up to four people which travel between the two plant sites that lie $70 \mathrm{~km}$ apart (cf. Table 2). For these trips the EV was accessible from 8 am until $8 \mathrm{pm}$. The available time for charging on both ends could only be estimated with an average duration of $2 \mathrm{~h}$, i.e., the average duration of one meeting or the time frame between the arrival of one group and the departure of the next. 
Postprint of article "Charging strategies for economic operations of electric vehicles in commercial applications." In Transportation research / D, 51, 173-189. doi:10.1016/j.trd.2016.11.032 [?

\subsubsection{Strategy 2.1: Solely relying on fast charging}

Strategy 2.1 was developed by taking into account the technological data of the charging process, the energy consumption, and the required availability. A complete AC charge (mode 2) lasts up to $10 \mathrm{~h}$. The effective charging power measured at the outlet is about $2.3 \mathrm{~kW}$, and the effective charging power of the battery is $2.1 \mathrm{~kW}$ (cf. Fig. 9 and Table 7). With the avail-able charging times during the day of about two hours between trips, the conventional $2.1 \mathrm{~kW}$ charging does not provide a sustainable solution for this strategy. Hence, at both plant sites the installed DC fast charging EVSE with $50 \mathrm{~kW}$ peak charging power was used. However due to local grid limitations the charging power in France was limited to $20 \mathrm{~kW}$. Under ideal conditions the $50 \mathrm{~kW}$ fast charging process is ended by the Nissan Leaf's battery management system (BMS) after reaching around $90 \% \mathrm{SOC}$ at about $30 \mathrm{~min}$.

Independent from the charging power and the SOC level, the DC fast charging process is ended by this vehicle's BMS after one hour latest. In both cases a manual restart is possible (cf. Fig. 10 and Table 8).

Fig. 8 illustrates the strategy's timeline for two example days, the first with one and the second with two trips and retours per day. By doing 1.5 trips on average per day, which was roughly the number of total trips before the deployment of the EV, the result would be an annual mileage of around 50,000 $\mathrm{km}$. With one hour per tour, one hour $(20 \mathrm{~kW})$ in France and $30 \mathrm{~min}(50 \mathrm{~kW})$ in Germany per charge, this leads on average to three hours of driving, $2.25 \mathrm{~h}$ of charging, and $18.75 \mathrm{~h}$ of idle time per day (cf. Fig. 8).

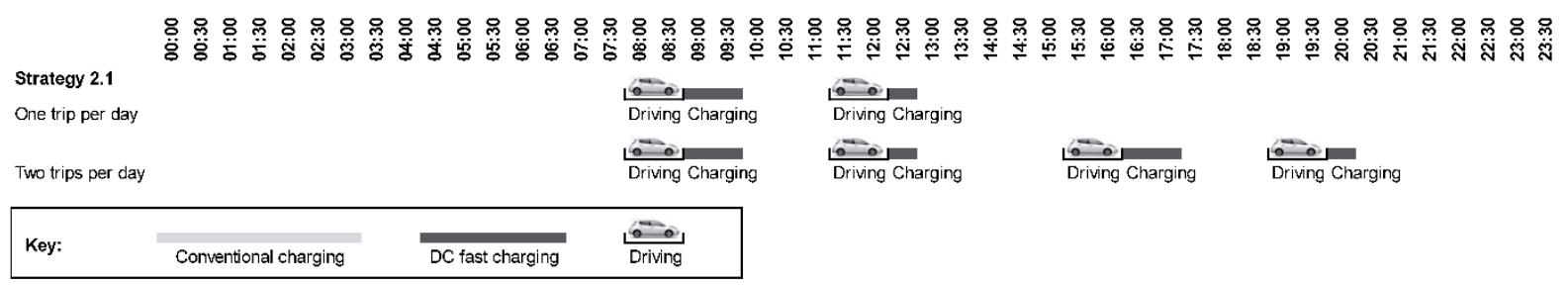

Figure 8: Illustration of the business trip charging strategy 2.1

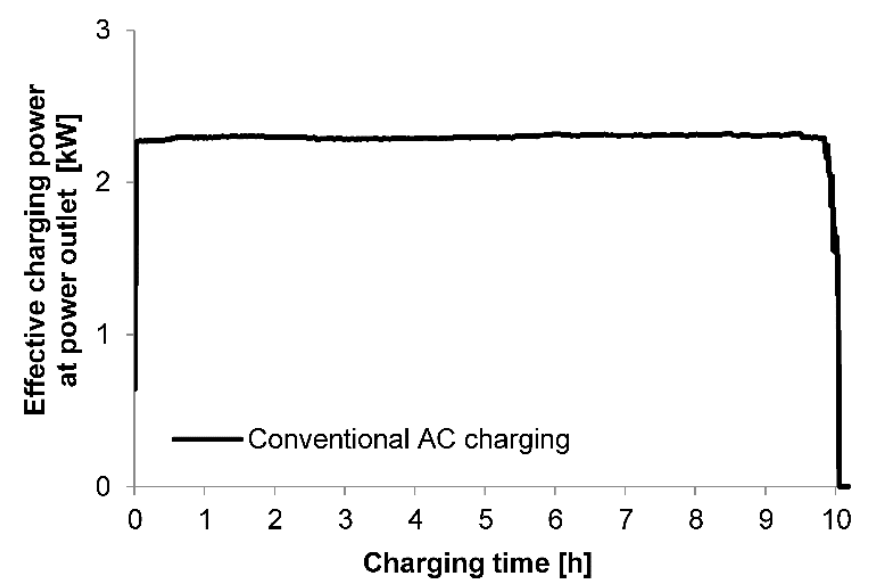

Figure 9: Conventional AC charging curve of the Nissan Leaf 
Postprint of article "Charging strategies for economic operations of electric vehicles in commercial applications." In Transportation research / D, 51, 173-189. doi:10.1016/j.trd.2016.11.032匹

\begin{tabular}{lr}
\hline & Nissan Leaf \\
\hline SOC span & $0-100 \%$ \\
$\begin{array}{l}\text { Charging time for a full } \\
\text { recharge }[\mathrm{h}]\end{array}$ & 10.26 \\
$\begin{array}{l}\text { Max. effective charging } \\
\text { power at outlet }[\mathrm{kW}]\end{array}$ & 2.32 \\
$\begin{array}{l}\text { Max. effective battery } \\
\text { charging power }[\mathrm{kW}]\end{array}$ & 2.10
\end{tabular}

\section{Table 7: Data conventional AC charging curve of the Nissan Leaf}

During operation two problems occurred with this charging strategy. Both can directly be linked to the exclusive use of DC fast charging and the fact that this vehicle version's BMS automatically limits the fast charging process to one hour latest (cf. Fig. 10). The first problem was the fading of the battery's capacity: after only about $4000 \mathrm{~km}$ the vehicle's SOH display indicated a considerable decrease. The reason identified for this fast capacity fade was the missing passive balancing of the individual battery cells' voltage. The passive balancing process takes time; since the charging process is ended by the EV after one hour at the latest, there was no time for passive balancing of the battery. The second problem with the autonomous switch-off was an insufficient charging level. Due to $\mathrm{SOH}$ considerations depending on the temperature the charging power is automatically reduced by the BMS. The forced switch-off after one hour lead in extreme situations to an insufficient SOC to ensure a safe journey back. Based on these problems with the execution of charging strategy 2.1, strategy 2.2 was set up.

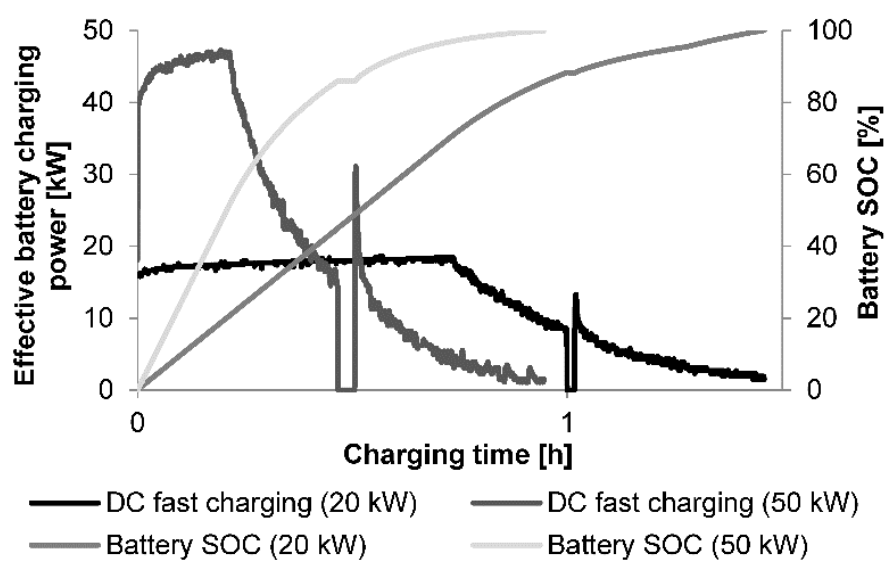

Figure 10: DC fast charging curves of the Nissan Leaf

\begin{tabular}{lrr}
\hline & $\begin{array}{r}\text { Nissan Leaf } \\
(\mathbf{2 0} \mathbf{~ k W})\end{array}$ & $\begin{array}{r}\text { Nissan Leaf } \\
\mathbf{( 5 0} \mathbf{~ k W})\end{array}$ \\
\hline SOC span & $0-100 \%$ & $0-100 \%$ \\
$\begin{array}{l}\text { Charging time for a } \\
\text { full recharge [h] }\end{array}$ & $<1.5$ & $<1.0$ \\
$\begin{array}{l}\text { Max. effective } \\
\text { charging power at } \\
\text { outlet [kW] }\end{array}$ & 20 & 50 \\
$\begin{array}{l}\text { Max. effective battery } \\
\text { charging power [kW] }\end{array}$ & 18.4 & 47.5 \\
\hline Table 8: Data DC fast charging curves of the Nissan Leaf
\end{tabular}


Postprint of article "Charging strategies for economic operations of electric vehicles in commercial applications." In Transportation research / D, 51, 173-189. doi:10.1016/j.trd.2016.11.032 [?

\subsubsection{Strategy 2.2: Relying on fast charging for the day and conventional charging (mode 2) at night}

Charging strategy 2.2 includes not only fast charging during the day, but also conventional AC charging overnight (cf. Fig. 11). This addresses both problems that occurred in strategy 2.1: the conventional charging overnight provides more than enough time for passive balancing voltage levels of battery cells. After the introduction of overnight conventional AC charging, the $\mathrm{SOH}$ remained constantly at the reset level. The AC charging also allows preconditioning of the EV. The Nissan Leaf can be heated or cooled before use in the morning by energy taken directly from the power grid, which in turn increases the range of the vehicle. The new charging strategy ensures that even under low temperatures all the requirements concerning functionality and availability are met, while at the same time protecting the $\mathrm{SOH}$. In this charging strategy the average time of driving and fast charging per day remains constant at 3 or $2.25 \mathrm{~h}$ respectively. However, about 12 out of the remaining $18.75 \mathrm{~h}$ are now used for recharging, balancing, and preconditioning.

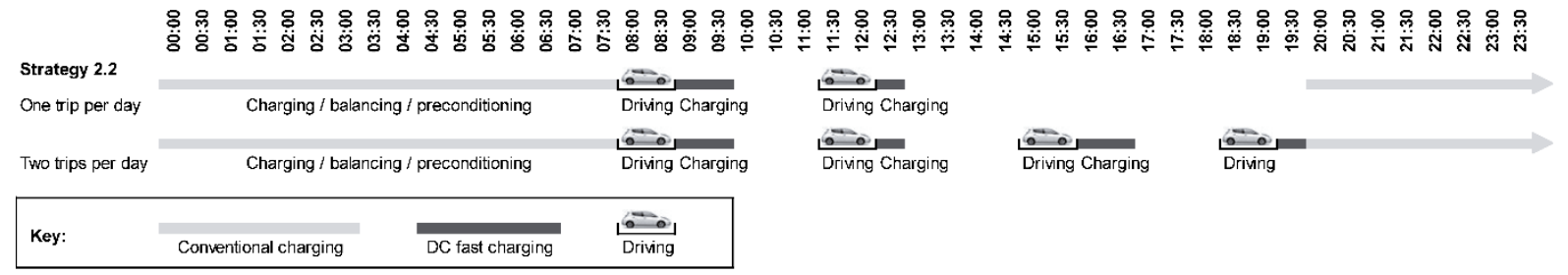

Figure 11: Illustration of the business trip charging strategy 2.2 including $A C$ charging overnight

\section{Discussion}

The outcomes of this field test provide evidence for an ecologically and economic sensible application of EV. Furthermore, they support previous findings and claimed concepts, but also provide new insights and conceptual suggestions for the optimal outlay of EV charging strategies for a predetermined mobility application. The presented charging strategies are based on three types of input factors originating from the charging processes, the deployed EV, and the mobility applications.

Contrary to most studies investigating charging behavior and strategies, for the five presented strategies the charging places and times are predetermined by the underlying application. The charging points considered (at plant sites and at private homes) concur with current empirical research studies, which show that most EV are charged at home and at work; public charging plays a less important role (Robinson et al., 2013; Skippon and Garwood, 2011).

In the literature, the main distinction with regard to the timing of charging relates to the electricity market. Therefore, the start of the charging process relative to the arrival and the time of day are focused on. With all five presented strategies, which try to maximize the annual mileage, there was significantly less flexibility in timing of the charging process compared to most other applications (Franke and Krems, 2013; Robinson et al., 2013). Considering the distribution of charging events during the day, the commuter strategies lead to an almost even distribution due to the $24 \mathrm{~h}$ rolling shift schedule. For the business trips most charging events happen during the day, which on a greater scale would mean putting additional electricity demand on the grid during peak times.

\subsection{Key performance indicators to assess and compare EV charging strategies}

To our knowledge the analysis of charging strategies at this level of detail is new in current literature. To characterize and compare the five different charging strategies it became clear that using only the ratio of driving time to parking time as can be found in other studies (Camus et al., 2011; Lunz et al., 2012; Speidel and Bräunl, 2014) was insufficient. Therefore, this study proposes five KPI using different technical dimensions: the average daily distance travelled, the average idle time per day, the 
Postprint of article "Charging strategies for economic operations of electric vehicles in commercial applications." In Transportation research / D, 51, 173-189. doi:10.1016/j.trd.2016.11.032 [?

average ratio of driving to charging hours per day, the average ratio of fast to conventional charging events per day, and the average ratio of energy charged through fast and conventional charging per day.

The comparison of these key indicators amongst the five strategies illustrates the individual advantages and shortcomings (cf. Table 9). The increase in the daily distance travelled between the commuting strategies $1.1,1.2$, and 1.3 does not lead to a constant reduction of idle time. On the contrary, due to the introduction of fast charging, the average idle time actually almost doubles from 5 to $9 \mathrm{~h}$ in strategy 1.2. However, in strategy 1.3 the EV virtually have no idle time. Between 1.2 and 1.3 even though the daily distance covered increases by almost $50 \%$ and the number of charging events increases from 3 to 6 , due to a more balanced charging distribution the ratio of driving to charging time decreases and less energy is recharged through fast charging in total as well as relative to the amount conventionally charged. The highest amount of idle time and the highest ratio of driving to charging can be found in the business travel strategy 2.1, where on average the EV is charged faster than it is discharged through driving. This combination illustrates the reasoning behind the adaptation from 2.1 to 2.2: not only is the objective of high availability fulfilled, but also the potential degeneration of battery cells is limited. Since the EV is not used overnight, the fast charging can be combined with conventional charging, even if it is mainly done for balancing and preconditioning. Three of the five strategies have an average daily distance of over $200 \mathrm{~km}$, but differ significantly in the remaining values of their key indicators. Strategy 2.2 has the lowest amount of idle time, but strategy 1.2 is more balanced between conventional and fast charging. These examples illustrate that the KPI individually are insufficient to characterize and evaluate a charging strategy. In combination they can serve as a sufficient basis for comparing and evaluating charging strategies based on constant mobility applications.

Comparing the time distribution of charging and driving in the different strategies to the values in the literature it becomes evident that even in the strategies with high annual mileage, driving only makes up a small proportion of the total time of day. The values in this study lie between $3 \mathrm{~h}$ in strategy 1.1 $(12.5 \%)$ and $6 \mathrm{~h}$ in strategy $1.3(25 \%)$. Accordingly, $75-87.5 \%$ of the day consist of charging and idle time. Compared to the $91.7 \%$ ( $22 \mathrm{~h}$ ) by Guille and Gross (2009), the $95 \%$ by Camus et al. (2011), and 96.15\% by Speidel and Bräunl (2014) the values reached are significantly lower. A comparison of these values has to be done carefully, since the distribution of charging and driving time is highly dependent on the average speed and therefore average discharge power. Nevertheless, in this project, even when travelling $300 \mathrm{~km}$ per day, most of the time the EV stands still.

\begin{tabular}{|c|c|c|c|c|c|}
\hline $\begin{array}{l}\text { Key performance } \\
\text { indicators } \\
\text { (daily average) }\end{array}$ & $\begin{array}{c}\text { Strategy } \\
1.1\end{array}$ & Strategy 1.2 & $\begin{array}{c}\text { Strategy } \\
1.3\end{array}$ & $\begin{array}{l}\text { Strategy } \\
2.1\end{array}$ & Strategy 2.2 \\
\hline Distance travelled & $\sim 150 \mathrm{~km}$ & $\sim 225 \mathrm{~km}$ & $\sim 300 \mathrm{~km}$ & $\sim 210 \mathrm{~km}$ & $\sim 210 \mathrm{~km}$ \\
\hline Idle time & $5 \mathrm{~h}$ & $9 \mathrm{~h}$ & $\mathrm{Oh}$ & $18 \mathrm{~h}$ & $6 \mathrm{~h}$ \\
\hline $\begin{array}{l}\text { Ratio of driving time to } \\
\text { charging time }\end{array}$ & $\begin{array}{c}0.19 \\
(3 \mathrm{~h} / 16 \mathrm{~h})\end{array}$ & $\begin{array}{c}0.43 \\
(4.5 \mathrm{~h} / 10.5 \mathrm{~h})\end{array}$ & $\begin{array}{c}0.33 \\
(6 \mathrm{~h} / 18 \mathrm{~h})\end{array}$ & $\begin{array}{c}1.33 \\
(3 \mathrm{~h} / 2.25 \mathrm{~h})\end{array}$ & $\begin{array}{c}0.21 \\
(3 \mathrm{~h} / 14.25 \mathrm{~h})\end{array}$ \\
\hline $\begin{array}{l}\text { Ratio of started fast } \\
\text { charging to conventional } \\
\text { charging events }\end{array}$ & $\begin{array}{c}0 \\
(0 / 2)\end{array}$ & $\begin{array}{c}1 \\
(1.5 / 1.5)\end{array}$ & $\begin{array}{c}1 \\
(3 / 3)\end{array}$ & $\begin{array}{l}\text { undef. } \\
(1.5 / 0)\end{array}$ & $\begin{array}{c}1.5 \\
(1.5 / 1)\end{array}$ \\
\hline $\begin{array}{l}\text { Ratio of energy recharged } \\
\text { through fast and } \\
\text { conventional charging }\end{array}$ & $\begin{array}{c}0 \\
(0 / 34.5)\end{array}$ & $\begin{array}{c}2.49 \\
(36.9 / 14.85)\end{array}$ & $\begin{array}{c}0.90 \\
(32.7 / 36.3)\end{array}$ & $\begin{array}{l}\text { Only fast } \\
\text { charging }\end{array}$ & $\begin{array}{l}\text { Conventional } \\
\text { mainly for } \\
\text { balancing }\end{array}$ \\
\hline
\end{tabular}

Table 9: Key performance indicators of the presented charging strategies 
Postprint of article "Charging strategies for economic operations of electric vehicles in commercial applications." In Transportation research / D, 51, 173-189. doi:10.1016/j.trd.2016.11.032 [?

\subsection{Lessons learned}

The conclusions drawn from evaluating the charging strategies, the adaptations made in the process, and the KPI introduced reveal three distinctive outcomes concerning the nature of the underlying application, the required input parameters, and the choice of charging power.

The differences in the charging strategies between the commuting and the business trips show that, the more predictable the underlying mobility application the better the charging strategy can be adapted to it. Based on the fixed shift schedule for commuters all the charging times were fully predictable. Therefore, the timing of the charging and the required charging power could be chosen accordingly. Since for the business trips the duration of meetings or the departure of the next group was unknown, during the day the maximum charging power was always applied, even though it places more strain one the battery and the grid. A higher predictability not only leads to a less excessive use of fast charging, but also opens up the possibility for including other objectives such as decreasing the degradation of the battery or providing services to the electricity grid.

The field test indicates that in addition to the characteristics of the underlying mobility application, such as the starting and ending points, the travel times and distances covered, two factors need to be considered when developing a charging strategy: the features of the charging curve and the real (temperature and driving style dependent) energy consumption.

The comparison of the five charging curves presented in this study indicates that three characteristics are essential to develop a sustainable charging strategy: the maximum charging power, the duration of a full recharge, and the shape of the charging curve. The conventional AC charging curves for both EV types are similar, differing only slightly in their shape (cf. Figs. 2 and 9), whereas the charging power remains constant relative to the maximum charging power. Hence, the maximum charging power can be taken as a reliable indicator to simulate the recharge process. The DC fast charging curves on the other hand show a different progression (cf. Figs. 5 and 10). Therefore, for including fast charging in a sustainable charging strategy it is not sufficient just to rely on the nominal maximum charging power (C-rate) - the shape and the total duration of the charging process also need to be considered. This is illustrated by strategy 1.3: since the higher charging power is only available at lower SOC, even though the strategy is sustainable the SOC value never rises above $90 \%$ (cf. Fig. 7). Accordingly, various EV manufacturers provide not only estimations for a full fast charging recharge, but also for the duration of an $80 \%$ recharge. Strategy 1.2 shows that for an optimal charging strategy two distinct charging levels are not enough: the conventional charging is insufficient, but the fast charging requires far less time than the $8.5 \mathrm{~h}$ available. To allow the setting of a flexible charging power in a predetermined range could even further benefit the system. Concerning the application-specific real EV energy consumption, the results of this field test emphasize that real consumption can be significantly higher than values based on the New European Drive Cycle (NEDC) stated by the manufacturers depending on various factors, such as route profile, driving behavior, or the use of auxiliaries (Lorf et al., 2013; Muneer et al., 2015; Travesset-Baro et al., 2015; Wu et al., 2015). For the present field test the high occupancy rate of the EV (about 5 people per EV in average) and high average speed of around $55 \mathrm{~km} / \mathrm{h}$ can be identified as one reason for the observed discrepancy.

\subsection{Technological and economic implications}

Considering the charging strategies and the market technology available at the time of the field test, it becomes evident that with high utilization of EV the cycle life of the battery cells becomes an issue. Apart from the standard degradation of parts such as tires, brakes, etc., the battery ages in intensive use. Over the course of a year the strategies in use lead to a different number of charging events as can be seen in Table 10. The DOD for each trip is considered constant for each strategy, since the travelled distances do not change. Applying a higher number of charging cycles allows a higher (daily) mileage, but due to cyclical effects it also affects battery life (Neubauer et al., 2012). Many battery cell manufacturers state a ten year life-time based on calendar life and at least 3000 full charge and discharge cycles before reaching their end of life at 80\% capacity (Azadfar et al., 2015; Kley, 2011). 
Postprint of article "Charging strategies for economic operations of electric vehicles in commercial applications." In Transportation research / D, 51, 173-189. doi:10.1016/j.trd.2016.11.032 [?

For the presented charging strategies and the associated DOD per trip, neglecting effects due to fast charging or different SOC levels regarding the cell chemistry, which goes beyond the scope of this work, the estimated cycle life of 3000 cycles varies from 4.2 to 11.1 years. As can be seen from these values in Table 10 the calendar life of the battery of ten years and beyond plays no significant role, since for all but one charging strategy the predicted cycle life values are distinctly lower than the calendar life. The actual SOC range used on both trip directions indicates that for all strategies there is potential to avoid high and low SOC levels (cf. Table 10). Due to the fact that at these levels it is more likely that harmful chemical side reactions occur, it is always good to avoid these states. This could prolong the battery life, but it requires external control of the EV BMS to limit the maximum SOC.

Evaluating the technologically possible annual and EV lifetime mileage from an economic point of view, the deployment of $E V$ in the considered mobility applications can potentially become less costly than the use of ICEV. Various studies have compared and discussed the TCO of EV and ICEV (Plötz et al., 2013; Tseng et al., 2013; Windisch, 2013). In general, the TCO is influenced by two kinds of factors: technological factors and regional factors. Technological factors are for example the price and durability of the EV, especially that of the battery cells, or the basis of comparison to the ICEV, e.g. engine power. Regional factors can be energy prices, taxes, incentives, and other market circumstances, which are dependent on the respective country (Feng and Figliozzi, 2013; Plötz et al., 2013; Sharma et al., 2012). Considering the high sensitivity of a TCO analysis to these various factors no definite statements can be made based solely on the annual or lifetime mileage of an EV. In particular due to a lack of empirical evidence and fast technological progress, the residual value of the battery and therefore a successful market penetration of EV is still uncertain (Plötz et al., 2013). However, taking the annual or lifetime mileage can serve as an indicator for potential competitiveness. Various TCO analyses have shown that despite the savings in variable costs at current market prices and production processes, an annual mileage of $20,000 \mathrm{~km}$, which is about the average of the German commercial fleet (Wermuth et al., 2012), is insufficient to reach an economic break-even in comparison to ICEV in Germany (Plötz et al., 2013). Hacker et al. (2015) calculate that in 2014 the barrier lies at 30,400 km in an optimistic scenario; Richter and Lindenberger (2010) estimate that for Germany in 2020 at least $27,000 \mathrm{~km}$ annual mileage is required while Kasten et al. (2011) even state a required annual mileage of $34,750 \mathrm{~km}$ in 2020 to break even. For the US market Feng and Figliozzi (2013) come to the conclusion that for commercial vehicles the competitiveness starts at 16,00022,000 miles $(25,750-35,400 \mathrm{~km})$, depending on the conditions; Tseng et al. (2013) state a total of around 150,000 miles $(241,000 \mathrm{~km})$ over a lifetime of ten years for passenger cars. For the Australian market Sharma et al. (2012) show that a mile-age of $150,000 \mathrm{~km}$ in ten years under the current conditions is insufficient. For France Windisch (2013) calculate a minimum of $30,000 \mathrm{~km}$ per year for seven years leading to a total of $210,000 \mathrm{~km}$ as break-even point. However, based on the average EU market conditions Faria et al. (2013) come to the conclusion that for the Nissan Leaf an annual mileage of $20,000 \mathrm{~km}$ in $8-9$ years is sufficient to become competitive. The high discrepancy in the results illustrates the difficulty of feasibility statements solely based on mileage. Comparing all the listed mileages to the annual as well as lifetime mileages that can potentially be reached with the presented charging strategies and technology at hand, it becomes evident that the values in this study are significantly higher than the break-even values that can be found in the literature. This clearly indicates that the presented charging strategies can distinctly contribute to a potentially competitive EV use in commercial applications. 
Postprint of article "Charging strategies for economic operations of electric vehicles in commercial applications." In Transportation research / D, 51, 173-189. doi:10.1016/j.trd.2016.11.032匹]

\begin{tabular}{|c|c|c|c|c|c|}
\hline \multirow{2}{*}{$\begin{array}{l}\text { EV } \\
\text { Strategy }\end{array}$} & \multicolumn{3}{|c|}{ e-Wolf Delta 2 EVO } & \multicolumn{2}{|c|}{ Nissan Leaf } \\
\hline & 1.1 & 1.2 & 1.3 & 2.1 & 2.2 \\
\hline Annual mileage & $\sim 36,000 \mathrm{~km}$ & $\sim 72,000 \mathrm{~km}$ & $\sim 100,000 \mathrm{~km}$ & $\sim 50,000 \mathrm{~km}$ & $\sim 50,000 \mathrm{~km}$ \\
\hline $\begin{array}{l}\text { Number of conventional } \\
\text { charging events per year }\end{array}$ & 500 & 500 & 1,000 & & $\begin{array}{l}\text { Passive } \\
\text { balancing }\end{array}$ \\
\hline $\begin{array}{l}\text { Number of fast charging } \\
\text { events per year }\end{array}$ & & 500 & 1,000 & 750 & 750 \\
\hline $\begin{array}{l}\text { Total charging events per } \\
\text { year }\end{array}$ & 500 & 1,000 & 2,000 & 750 & 750 \\
\hline $\begin{array}{l}\text { SOC range used } \\
\text { (in stable conditions) }\end{array}$ & $\sim 46-100 \%$ & 23-100\% & $\sim 51-90 \%$ & $\sim 32-100 \%$ & 32-100\% \\
\hline $\begin{array}{l}\text { Depth of discharge per } \\
\text { trip (Energy } \\
\text { consumed/capacity) }\end{array}$ & $54 \%$ & $54 \%$ & $36 \%$ & $58 \%$ & $58 \%$ \\
\hline $\begin{array}{l}\text { Number of full charging } \\
\text { cycles per year (Charging } \\
\left.\text { events }{ }^{\star} D O D\right)\end{array}$ & 270 & 540 & 720 & 435 & 435 \\
\hline $\begin{array}{l}\text { Estimated cycle life } \\
\text { (based on } 3,000 \text { cycles) }\end{array}$ & 11.1 years & 5.6 years & 4.2 years & 6.9 years & 6.9 years \\
\hline
\end{tabular}

Table 10: Prediction of cycle life in different charging strategies

\section{Conclusion}

This study adds new empirical insights and conceptual suggestions to the EV charging literature by presenting and dis-cussing charging strategies for two commercial mobility applications with constant mobility demand and fixed routes: the commuting of shift workers and business trips of employees. The five charging strategies, which were developed to increase the economic feasibility and therefore the annual mileage of EV in two mobility applications, were tested in a French-German field test from early 2013 to the end of 2015 . During this time over $450,000 \mathrm{~km}$ were travelled by the seven EV deployed. First and foremost, the results demonstrate how specifically developed and adapted charging strategies can lead to a high annual mileage by relying on more than one level of charging power. In particular, the inclusion of $D C$ fast charging with charging rates of $1 \mathrm{C}$ or higher is shown to be indispensable when trying to reach a high EV operating grade. Nevertheless, the results also provide indications that there are limits to fast charging, that to avoid unnecessary damage to the battery cells it should only be applied when required by the underlying mobility demand. To illustrate and assess charging strategies five KPI are suggested. They can also be applied to evaluate and compare different charging strategies, by for example revealing an avoidably high amount of idle time as a consequence of an unnecessarily frequent use of fast charging. The results further reveal that the more predictable the underlying mobility application the easier the charging strategy can be adapted accordingly. For this adaptation the empirical examples suggest a range of input parameters required for developing a balanced charging strategy, such as the features of the charging curve and the real energy consumption of the EV in use. Overall, the results and discussion underline how important a carefully designed charging strategy is for technological, environmental and economic sensible EV deployment and that charging time under the condition of high mobility demand becomes a critical component on the way to feasible EV deployment. 
Postprint of article "Charging strategies for economic operations of electric vehicles in commercial applications." In Transportation research / D, 51, 173-189. doi:10.1016/j.trd.2016.11.032 [?

Considering the research method, setting, and focus of the study, the transfer of the findings and conclusions into a broader context must be carried out carefully. Limitations lie especially in the research method: the early stage long-term field test of two mobility applications served with two different types of EV is insufficient for a broad generalization. The results show that particularly the technological features of EV have a strong influence on the charging strategies. The charging curves for example, which are a substantial part, are highly dependent on the EV individual BMS, and thus they vary for each EV. All charging curves presented in this study are recorded under ideal circumstances. Our experience in the project shows that especially under high or low battery temperatures the BMS lower the charging power of both conventional and DC fast charging processes to avoid harming the battery cells.

Based on the results future research could expand into three directions. Firstly, it could take the presented field test as an empirical starting point for developing an optimization model of charging patterns comparable to Bashash et al. (2011). However, instead of only using one charging power level to balance the annual mileage with the cost of cycle ageing it could allow for more levels of charging power. As indicated by the used SOC range (cf. Table 10) for most charging strategies the battery capacity could be reduced, which could lower the production costs. However, there is a tradeoff with increasing ageing effects. Hence, a different approach with a fixed target mileage could allow different levels of battery capacity as additional decision variables in the optimization model. Secondly, the presented mobility applications show highly predictable demand patterns. However, for many commercial applications and private users the demand per vehicle is less predictable. Therefore, future research could also expand the detailed analysis of charging strategies by including stochastic models for optimization similar to Iversen et al. (2014) or Škugor and Deur (2015). Thirdly, the field test could be expanded based on the available detailed data by an analysis of the thermal behavior and thermal limits of DC fast charging in EV deployment, especially when there is no active cooling of the cells. Last but not least, the EV and battery technology is improving fast. There-fore, similar field tests could be conducted with future EV generations and compared to this early stage set up.

\section{Acknowledgements}

The authors thank the German Federal Ministry of Transport and Digital Infrastructure for supporting the research by funding the RheinMobil project [ref. no: 16SBW007A] as part of the Federal Government's Schaufenster initiative. They also thank their industrial and research partners of the RheinMobil project consortium, who contributed support, time, and fund-ing to make the project possible. A special thanks goes to our colleague James Barry for his valuable comments concerning the English language. 
Postprint of article "Charging strategies for economic operations of electric vehicles in commercial applications." In Transportation research / D, 51, 173-189. doi:10.1016/j.trd.2016.11.032 [?

\section{References}

Agubra, V., Fergus, J., 2013. Lithium Ion Battery Anode Aging Mechanisms. Materials (Basel). 6, 1310-1325. doi:10.3390/ma6041310

Alexander, M., Davis, M., 2013. Total Cost of Ownership Model for Current Plug-in Electric Vehicles 2013. Palo Alto.

Atia, R., Yamada, N., 2015. More accurate sizing of renewable energy sources under high levels of electric vehicle integration. Renew. Energy 81, 918-925. doi:10.1016/j.renene.2015.04.010

Axsen, J., Kurani, K.S., McCarthy, R., Yang, C., 2011. Plug-in hybrid vehicle GHG impacts in California: Integrating consumer-informed recharge profiles with an electricity-dispatch model. Energy Policy 39, 1617-1629. doi:10.1016/j.enpol.2010.12.038

Azadfar, E., Sreeram, V., Harries, D., 2015. The investigation of the major factors influencing plug-in electric vehicle Agubra, V., Fergus, J., 2013. Lithium ion battery anode aging mechanisms. Materials (Basel) 6, 1310-1325. http://dx.doi.org/10.3390/ma6041310.

Alexander, M., Davis, M., 2013. Total Cost of Ownership Model for Current Plug-in Electric Vehicles 2013. Palo Alto.

Atia, R., Yamada, N., 2015. More accurate sizing of renewable energy sources under high levels of electric vehicle integration. Renew. Energy 81, 918-925.

http://dx.doi.org/10.1016/j.renene.2015.04.010.

Axsen, J., Kurani, K.S., McCarthy, R., Yang, C., 2011. Plug-in hybrid vehicle GHG impacts in California: integrating consumer-informed recharge profiles with an electricity-dispatch model.

Energy Policy 39, 1617-1629. http://dx.doi.org/10.1016/j.enpol.2010.12.038.

Azadfar, E., Sreeram, V., Harries, D., 2015. The investigation of the major factors influencing plug-in electric vehicle driving patterns and charging behaviour.

Renew. Sustain. Energy Rev. 42, 1065-1076. http://dx.doi.org/10.1016/j.rser.2014.10.058.

Babrowski, S., Heinrichs, H., Jochem, P., Fichtner, W., 2014. Load shift potential of electric vehicles in Europe. J. Power Sources 255, 283-293. http://dx.doi. org/10.1016/j.jpowsour.2014.01.019.

Bashash, S., Moura, S.J., Forman, J.C., Fathy, H.K., 2011. Plug-in hybrid electric vehicle charge pattern optimization for energy cost and battery longevity. J.

Power Sources 196, 541-549. http://dx.doi.org/10.1016/j.jpowsour.2010.07.001.

Bickert, S., Kampker, A., Greger, D., 2015. Developments of $\mathrm{CO}_{2}$-emissions and costs for small

electric and combustion engine vehicles in Germany. Transp.

Res. Part D Transp. Environ. 36, 138-151.

Bishop, J.D.K., Axon, C.J., Bonilla, D., Banister, D., 2016. Estimating the grid payments necessary to compensate additional costs to prospective electric vehicle owners who provide vehicle-to-grid ancillary services. Energy 94, 715-727. http://dx.doi.org/10.1016/j.energy.2015.11.029.

Broussely, M., Biensan, P., Bonhomme, F., Blanchard, P., Herreyre, S., Nechev, K., Staniewicz, R.J., 2005. Main aging mechanisms in Li ion batteries. J. Power Sources 146, 90-96.

http://dx.doi.org/10.1016/j.jpowsour.2005.03.172.

Brunnert, S., 2012. Modellierung des technisch-wirtschaftlichen Einsatzpotentials von

Elektrofahrzeugen in Großstädten. Technische Universität München. Bunce, L., Harris, M., Burgess,

M., 2014. Charge up then charge out? Drivers' perceptions and experiences of electric vehicles in the

UK. Transp. Res. Part A

Policy Pract. 59, 278-287. http://dx.doi.org/10.1016/j.tra.2013.12.001.

Camus, C., Farias, T., Esteves, J., 2011. Potential impacts assessment of plug-in electric vehicles on the Portuguese energy market. Energy Policy 39, 5883- 5897.

http://dx.doi.org/10.1016/j.enpol.2011.06.042.

Chandrasekaran, R., 2014. Quantification of bottlenecks to fast charging of lithium-ion-insertion cells

for electric vehicles. J. Power Sources, 1-11. http://dx. doi.org/10.1016/j.jpowsour.2014.07.106.

Creutzig, F., Jochem, P., Edelenbosch, O.Y., Mattauch, L., van Vuuren, D.P., McCollum, D., Minx, J., 2015. Energy and environment. Transport: a roadblock to climate change mitigation? Science 350 , 911-912. http://dx.doi.org/10.1126/science.aac8033.

Dallinger, D., Krampe, D., Wietschel, M., 2011. Vehicle-to-grid regulation reserves based on a dynamic simulation of mobility behavior. IEEE Trans. Smart Grid 2, 302-313. http://dx.doi.org/10.1109/TSG.2011.2131692. 
Postprint of article "Charging strategies for economic operations of electric vehicles in commercial applications." In Transportation research / D, 51, 173-189. doi:10.1016/j.trd.2016.11.032 [?

Dharmakeerthi, C.H., Mithulananthan, N., Saha, T.K., 2014. Impact of electric vehicle fast charging on power system voltage stability. Int. J. Electr. Power Energy Syst. 57, 241-249. http://dx.doi.org/10.1016/j.ijepes.2013.12.005.

Donateo, T., Licci, F., D'Elia, A., Colangelo, G., Laforgia, D., Ciancarelli, F., 2015. Evaluation of emissions of $\mathrm{CO}_{2}$ and air pollutants from electric vehicles in Italian cities. Appl. Energy. http://dx.doi.org/10.1016/j.apenergy.2014.12.089.

Dudenhöffer, K., Arora, R., Diverrez, A., Jochem, P., Tücking, J., 2014. Potentials for Electric Vehicles in France, Germany, and India (No. No. 5), Series in Production and Energy. Karlsruhe.

Dumortier, J., Siddiki, S., Carley, S., Cisney, J., Krause, R.M., Lane, B.W., Rupp, J.a., Graham, J.D., 2015. Effects of providing total cost of ownership information on consumers' intent to purchase a hybrid or plug-in electric vehicle. Transp. Res. Part A Policy Pract. 72, 71-86. http://dx.doi.org/10.1016/ j.tra.2014.12.005.

Ecker, M., Gerschler, J.B., Vogel, J., Käbitz, S., Hust, F., Dechent, P., Sauer, D.U., 2012. Development of a lifetime prediction model for lithium-ion batteries based on extended accelerated aging test data. J. Power Sources 215, 248-257. http://dx.doi.org/10.1016/j.jpowsour.2012.05.012.

Ensslen, A., Ringler, P., Jochem, P., Keles, D., Fichtner, W., 2014. About Business Model Specifications of a Smart Charging Manager to Integrate Electric Vehicles into the German Electricity Market. Rome, Italy.

Ensslen, A., Schuecking, M., Jochem, P., Steffens, H., Fichtner, W., Wollersheim, O., Stella, K., 2017. Empirical carbon dioxide emissions of electric vehicles in a French-German commuter fleet test. J. Clean. Prod. 142, 263-278. http://dx.doi.org/10.1016/j.jclepro.2016.06.087.

Faria, R., Marques, P., Moura, P., Freire, F., Delgado, J., de Almeida, A.T., 2013. Impact of the electricity mix and use profile in the life-cycle assessment of electric vehicles. Renew. Sustain. Energy Rev. 24, 271-287. http://dx.doi.org/10.1016/j.rser.2013.03.063.

Feng, W., Figliozzi, M., 2013. An economic and technological analysis of the key factors affecting the competitiveness of electric commercial vehicles: a case study from the USA market. Transp. Res. Part C Emerg. Technol. 26, 135-145. http://dx.doi.org/10.1016/j.trc.2012.06.007.

Fernández, I.J., Calvillo, C.F., Sánchez-Miralles, a., Boal, J., 2013. Capacity fade and aging models for electric batteries and optimal charging strategy for electric vehicles. Energy 60, 35-43. http://dx.doi.org/10.1016/j.energy.2013.07.068.

Franke, T., Krems, J.F., 2013. Understanding charging behaviour of electric vehicle users. Transp.

Res. Part F Traffic Psychol. Behav. 21, 75-89. http://dx.doi. org/10.1016/j.trf.2013.09.002.

Gnann, T., Plötz, P., Zischler, F., Wietschel, M., 2012. Elektromobilität im Personenwirtschaftsverkehr - eine Potenzialanalyse. Karlsruhe.

Graham-Rowe, E., Gardner, B., Abraham, C., Skippon, S., Dittmar, H., Hutchins, R., Stannard, J., 2012. Mainstream consumers driving plug-in battery-electric and plug-in hybrid electric cars: a qualitative analysis of responses and evaluations. Transp. Res. Part A Policy Pract. 46, 140-153. http://dx.doi.org/ 10.1016/j.tra.2011.09.008.

Greaves, S., Backman, H., Ellison, A.B., 2014. An empirical assessment of the feasibility of battery electric vehicles for day-to-day driving. Transp. Res. Part A Policy Pract. 66, 226-237. http://dx.doi.org/10.1016/j.tra.2014.05.011.

Guille, C., Gross, G., 2009. A conceptual framework for the vehicle-to-grid (V2G) implementation.

Energy Policy 37, 4379-4390. http://dx.doi.org/10.1016/j. enpol.2009.05.053.

Hacker, F., von Waldenfels, R., Mottschall, M., 2015. Wirtschaftlichkeit von Elektromobilität in gewerblichen Anwendungen (Abschlussbericht). Berlin. Hadley, S.W., Tsvetkova, A.A., 2009.

Potential impacts of plug-in hybrid electric vehicles on regional power generation. Electr. J., 56-68

Hahn, T., Schönfelder, M., Jochem, P., Heuveline, V., Fichtner, W., 2013. Model-based quantification of load shift potentials and optimized charging of electric vehicles. Smart Grid Renew. Energy 4, 398-408.

Harris, C.B., Webber, M.E., 2014. An empirically-validated methodology to simulate electricity demand for electric vehicle charging. Appl. Energy 126, 172-

181. http://dx.doi.org/10.1016/j.apen

ergy.2014.03.078. IEA, 2014.

Electricity Information 2014. 
Postprint of article "Charging strategies for economic operations of electric vehicles in commercial applications." In Transportation research / D, 51, 173-189. doi:10.1016/j.trd.2016.11.032 [?

Iversen, E.B., Morales, J.M., Madsen, H., 2014. Optimal charging of an electric vehicle using a Markov decision process. Appl. Energy 123, 1-12. http://dx.doi. org/10.1016/j.apenergy.2014.02.003.

Jansen, K.H., Brown, T.M., Samuelsen, G.S., 2010. Emissions impacts of plug-in hybrid electric vehicle deployment on the U.S. western grid. J. Power Sources 195, 5409-5416.

http://dx.doi.org/10.1016/j.jpowsour.2010.03.013.

Jochem, P., Babrowski, S., Fichtner, W., 2015. Assessing $\mathrm{CO}_{2}$ emissions of electric vehicles in Germany in 2030. Transp. Res. Part A Policy Pract. 78, 68-83. http://dx.doi.org/10.1016/j.tra.2015.05.007.

Jochem, P., Doll, C., Fichtner, W., 2016. External costs of electric vehicles. Transp. Res. Part D Transp. Environ. 42, 60-76. http://dx.doi.org/10.1016/j. trd.2015.09.022.

Kang, J.E., Recker, W.W., 2009. An activity-based assessment of the potential impacts of plug-in hybrid electric vehicles on energy and emissions using 1-day travel data. Transp. Res. Part D Transp. Environ. 14, 541-556. http://dx.doi.org/10.1016/j.trd.2009.07.012.

Kasten, P., Zimmer, W., Leppler, S., 2011. $\mathrm{CO}_{2}$ - Minderungspotenziale durch den Einsatz von elektrischen Fahrzeugen in Dienstwagenflotten. Freiburg. Ketelaer, T., Kaschub, T., Jochem, P., Fichtner, W., 2014. The potential of carbon dioxide emission reductions in German commercial transport by electric vehicles. Int. J. Environ. Sci. Technol. http://dx.doi.org/10.1007/s13762-014-0631-y.

Khoo, Y.B., Wang, C.-H., Paevere, P., Higgins, A., 2014. Statistical modeling of electric vehicle electricity consumption in the Victorian EV Trial, Australia. Transp. Res. Part D Transp. Environ. 32, 263-277. http://dx.doi.org/10.1016/j.trd.2014.08.017.

Kier, M., Weber, C., 2015. Dumm oder Smart? Implementierung von Ladestrategien für eine gewerbliche Elektromobilitätsflotte. In: Tagung Optimierung in Der Energiewirtschaft 2015, VDI Berichte 2266. VDI Wissensforum GmbH, Düsseldorf, pp. 29-41.

Kim, S.U., Albertus, P., Cook, D., Monroe, C.W., Christensen, J., 2014. Thermoelectrochemical simulations of performance and abuse in 50-Ah automotive cells. J. Power Sources 268, 625-633. http://dx.doi.org/10.1016/j.jpowsour.2014.06.080.

Kim, U.S., Yi, J., Shin, C.B., Han, T., Park, S., 2011. Modelling the thermal behaviour of a lithium-ion battery during charge. J. Power Sources 196, 5115-5121.

http://dx.doi.org/10.1016/j.jpowsour.2011.01.103.

Kley, F., 2011. Ladeinfrastrukturen für Elektrofahrzeuge. Fraunhofer Verlag, Karlsruhe.

Kristoffersen, T.K., Capion, K., Meibom, P., 2011. Optimal charging of electric drive vehicles in a market environment. Appl. Energy 88, 1940-1948. http://dx.

doi.org/10.1016/j.apenergy.2010.12.015.

Linssen, J., Schulz, A., Mischinger, S., Maas, H., Weinmann, O., Abbasi, E., Bickert, S., Danzer, M., Hennings, W., Lindwedel, E., Marker, S., Schindler, V., Schmidt, A., Schmitz, P., Schott, B., Strunz, K., Waldowski, P., 2012. Netzintegration von Fahrzeugen mit elektrifizierten Antriebssystemen in bestehende und zukünftige Energieversorgungsstrukturen. Forschungszentrum Jülich GmbH Zentralbibliothek, Verlag, Juelich.

Lorf, C., Martínez-Botas, R.F., Howey, D.A., Lytton, L., Cussons, B., 2013. Comparative analysis of the energy consumption and $\mathrm{CO}_{2}$ emissions of 40 electric, plug-in hybrid electric, hybrid electric and internal combustion engine vehicles. Transp. Res. Part D Transp. Environ. 23, 12-19. http://dx.doi.org/ 10.1016/j.trd.2013.03.004.

Lunz, B., Yan, Z., Gerschler, J.B., Sauer, D.U., 2012. Influence of plug-in hybrid electric vehicle charging strategies on charging and battery degradation costs. Energy Policy 46, 511-519. http://dx.doi.org/10.1016/j.enpol.2012.04.017.

Muneer, T., Milligan, R., Smith, I., Doyle, A., Pozuelo, M., Knez, M., 2015. Energetic, environmental and economic performance of electric vehicles: experimental evaluation. Transp. Res. Part D Transp. Environ. 35, 40-61. http://dx.doi.org/10.1016/j.trd.2014.11.015.

Neubauer, J., Brooker, A., Wood, E., 2012. Sensitivity of battery electric vehicle economics to drive patterns, vehicle range, and charge strategies. J. Power Sources 209, 269-277. http://dx.doi.org/10.1016/j.jpowsour.2012.02.107.

OECD, 2015. Economic Surveys: China 2013. http://dx.doi.org/10.1787/888932788056.

Offer, G.J., Yufit, V., Howey, D.A., Wu, B., Brandon, N.P., 2012. Module design and fault diagnosis in electric vehicle batteries. J. Power Sources 206, 383-392.

http://dx.doi.org/10.1016/j.jpowsour.2012.01.087. 
Postprint of article "Charging strategies for economic operations of electric vehicles in commercial applications." In Transportation research / D, 51, 173-189. doi:10.1016/j.trd.2016.11.032 [Z

Onda, K., Ohshima, T., Nakayama, M., Fukuda, K., Araki, T., 2006. Thermal behavior of small lithium-ion battery during rapid charge and discharge cycles. J.

Power Sources 158, 535-542. http://dx.doi.org/10.1016/j.jpowsour.2005.08.049.

Pantoš, M., 2011. Stochastic optimal charging of electric-drive vehicles with renewable energy. Energy 36, 6567-6576. http://dx.doi.org/10.1016/j.

energy.2011.09.006.

Plötz, P., Funke, S., Jochem, P., 2015. Real-world Fuel Economy and CO2 Emissions of Plug-in Hybrid Electric Vehicles (No. No. S 1/2015). Working Paper Sustainability and Innovation.

Plötz, P., Gnann, T., Kuehn, A., Wietschel, M., 2013. Markthochlaufszenarien für Elektrofahrzeuge (Langfassung). Karlsruhe.

Rahimian, S.K., Rayman, S., White, R.E., 2011. Optimal charge rates for a lithium ion cell. J. Power

Sources 196, 10297-10304. http://dx.doi.org/10.1016/j. jpowsour.2011.07.019.

Rangaraju, S., De Vroey, L., Messagie, M., Mertens, J., Van Mierlo, J., 2015. Impacts of electricity mix, charging profile, and driving behavior on the emissions performance of battery electric vehicles: a Belgian case study. Appl. Energy 148, 496-505. http://dx.doi.org/10.1016/j.apenergy.2015.01.121.

Richter, J., Lindenberger, D., 2010. Potentiale der Elektromobilität bis 2050. Köln.

Robinson, A.P., Blythe, P.T., Bell, M.C., Hübner, Y., Hill, G.A., 2013. Analysis of electric vehicle driver recharging demand profiles and subsequent impacts on the carbon content of electric vehicle trips. Energy Policy 61, 337-348. http://dx.doi.org/10.1016/j.enpol.2013.05.074.

Sharma, R., Manzie, C., Bessede, M., Brear, M.J., Crawford, R.H., 2012. Conventional, hybrid and electric vehicles for Australian driving conditions - Part 1:

technical and financial analysis. Transp. Res. Part C Emerg. Technol. 25, 238-249. http://dx.doi.org/10.1016/j.trc.2012.06.003.

Sierzchula, W., 2014. Factors influencing fleet manager adoption of electric vehicles. Transp. Res. Part D Transp. Environ. 31, 126-134. http://dx.doi.org/ 10.1016/j.trd.2014.05.022.

Skippon, S., Garwood, M., 2011. Responses to battery electric vehicles: UK consumer attitudes and attributions of symbolic meaning following direct experience to reduce psychological distance. Transp. Res. Part D Transp. Environ. 16, 525-531. http://dx.doi.org/10.1016/j.trd.2011.05.005.

Škugor, B., Deur, J., 2015. Dynamic programming-based optimisation of charging an electric vehicle fleet system represented by an aggregate battery model.

Energy 92, 456-465. http://dx.doi.org/10.1016/j.energy.2015.03.057.

Sohnen, J., Fan, Y., Ogden, J., Yang, C., 2015. A network-based dispatch model for evaluating the spatial and temporal effects of plug-in electric vehicle charging on GHG emissions. Transp. Res. Part D Transp. Environ. 38, 80-93. http://dx.doi.org/10.1016/j.trd.2015.04.014.

Speidel, S., Bräunl, T., 2014. Driving and charging patterns of electric vehicles for energy usage. Renew. Sustain. Energy Rev. 40, 97-110. http://dx.doi.org/ 10.1016/j.rser.2014.07.177.

Stella, K., Wollersheim, O., Fichtner, W., Jochem, P., Schücking, M., Nastold, M., Axel, E., Wietschel, M., Held, M., Gnann, T., Friedmann, M., Graf, R., Wohlfarth, K., 2015. Studie RheinMobil: Über $300.000 \mathrm{~km}$ unter Strom. Karlsruhe.

Sun, X.-H., Yamamoto, T., Morikawa, T., 2015a. Charge timing choice behavior of battery electric vehicle users. Transp. Res. Part D Transp. Environ. 37, 97-

107. http://dx.doi.org/10.1016/j.trd.2015.04.007.

Sun, X.-H., Yamamoto, T., Morikawa, T., 2015b. Stochastic frontier analysis of excess access to midtrip battery electric vehicle fast charging. Transp. Res.

Part D Transp. Environ. 34, 83-94. http://dx.doi.org/10.1016/j.trd.2014.10.006.

Thompson, T.M., King, C.W., Allen, D.T., Webber, M.E., 2011. Air quality impacts of plug-in hybrid electric vehicles in Texas: evaluating three battery charging scenarios. Environ. Res. Lett. 6, 1-11. http://dx.doi.org/10.1088/1748-9326/6/2/024004.

Tomic', J., Kempton, W., 2007. Using fleets of electric-drive vehicles for grid support. J. Power

Sources 168, 459-468. http://dx.doi.org/10.1016/j. jpowsour.2007.03.010.

Travesset-Baro, O., Rosas-Casals, M., Jover, E., 2015. Transport energy consumption in mountainous roads. A comparative case study for internal combustion engines and electric vehicles in Andorra. Transp. Res. Part D Transp. Environ. 34, 16-26.

http://dx.doi.org/10.1016/j.trd.2014.09.006. 
Postprint of article "Charging strategies for economic operations of electric vehicles in commercial applications." In Transportation research / D, 51, 173-189. doi:10.1016/j.trd.2016.11.032 [?

Tseng, H.-K., Wu, J.S., Liu, X., 2013. Affordability of electric vehicles for a sustainable transport system: an economic and environmental analysis. Energy Policy 61, 441-447.

http://dx.doi.org/10.1016/j.enpol.2013.06.026.

Vetter, J., Novák, P., Wagner, M.R., Veit, C., Möller, K.-C., Besenhard, J.O., Winter, M., WohlfahrtMehrens, M., Vogler, C., Hammouche, A., 2005. Ageing mechanisms in lithium-ion batteries. J. Power Sources 147, 269-281. http://dx.doi.org/10.1016/j.jpowsour.2005.01.006.

Wagner, A., 2014. International Fuel Prices 2012/2013. Eschborn, Germany.

Wermuth, M., Neef, C., Wirth, R., Hanitz, I., Löhner, H., Hautzinger, H., Stock, W., Pfeiffer, M., Fuchs, M., Lenz, B., Ehler, V., Schneider, S., Heinzmann, H.-J., 2012. Kraftfahrzeugverkehr in Deutschland 2010 (KiD 2010).

Windisch, E., 2013. Driving Electric? A Financial Assessment of Electric Vehicle Policies in France.

Wu, X., Freese, D., Cabrera, A., Kitch, W.A., 2015. Electric vehicles' energy consumption measurement and estimation. Transp. Res. Part D Transp. Environ. 34, 52-67. http://dx.doi.org/10.1016/j.trd.2014.10.007.

Wu, X., Hu, X., Moura, S., Yin, X., Pickert, V., 2016. Stochastic control of smart home energy management with plug-in electric vehicle battery energy storage and photovoltaic array. J. Power Sources 333, 203-212. http://dx.doi.org/10.1016/j.jpowsour.2016.09.157. 